\title{
Automatic Radioxenon Analyzer for CTBT Monitoring
}

T.W. Bowyer

K.H. Abel

W.K. Hensley

C.W. Hubbard

A.D. McKinnon
M.E. Panisko

R.W. Perkins

P.L. Reeder

R.C. Thompson

R.A. Warner

November 1996

Prepared for the U.S. Department of Energy under Contract DE-ACO6-76RLO 1830

Pacific Northwest National Laboratory Richland, Washington 99352

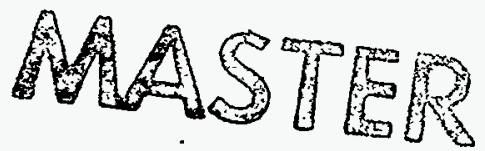

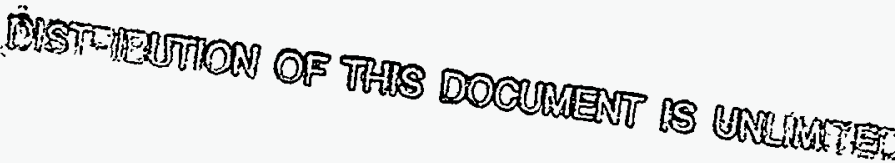




\section{DISCLAMIER}

Portions of this document may be illegible in electronic image products. Images are produced from the best available original document. 


\section{DISCLAIMER}

This report was prepared as an account of work sponsored by an agency of the United States Government. Neither the United States Government nor any agency thereof, nor any of their employees, make any warranty, express or implied, or assumes any legal liability or responsibility for the accuracy, completeness, or usefulness of any information, apparatus, product, or process disclosed, or represents that its use would not infringe privately owned rights. Reference herein to any specific commercial product, process, or service by trade name, trademark, manufacturer, or otherwise does not necessarily constitute or imply its endorsement, recommendation, or favoring by the United States Government or any agency thereof. The views and opinions of authors expressed herein do not necessarily state or reflect those of the United States Government or any agency thereof. 


\section{Summary}

Over the last three years, with guidance and support from the U.S. Department of Energy's NN-20 Comprehensive Test Ban Treaty Research and Development program, Pacific Northwest National Laboratory has developed and demonstrated a fully automatic analyzer for the collection and quantitative measurement of the four xenon radionuclides, ${ }^{131 m} \mathrm{Xe}(11.9 \mathrm{~d}),{ }^{133 m} \mathrm{Xe}(2.19 \mathrm{~d}),{ }^{133} \mathrm{Xe}(5.24 \mathrm{~d})$, and ${ }^{135} \mathrm{Xe}(9.10 \mathrm{~h})$, in the atmosphere. These radionuclides are important signatures in monitoring for compliance to a Comprehensive Test Ban Treaty. The activity ratios between certain of these radionuclides permit discrimination between radioxenon originating from nuclear detonations and that from nuclear reactor operations, nuclear fuel reprocessing, or from medical isotope production and usage.

With our system, xenon is continuously and automatically separated from the atmosphere at flow rates of about $7 \mathrm{~m}^{3} / \mathrm{h}$ by sorption-bed techniques. Aliquots collected for 6 to 12 hours are automatically analyzed by electron-photon coincidence spectrometry to provide sensitivities in the range of 20 to $100 \mu \mathrm{Bq} / \mathrm{m}^{3}$ of air. This sensitivity is about 100 -fold better than achieved with reported laboratory-based procedures (for example, DeGeer, 1995) for the short time collection intervals of interest. The large sensitivity improvement over reported laboratory techniques is due to a 10- to 25-fold higher sampling rate, a 3-to 4-fold higher counting efficiency, a $10^{3}$ - to $10^{4}$-fold lower background, the immediate analysis of the radioxenons following collection and purification, and the elimination of radon from the separated atmospheric xenon samples. Spectral data from the measurements are automatically analyzed, and the calculated radioxenon concentrations and raw gamma-ray spectra are automatically transmitted to data centers.

\section{Reference}

DeGeer, L.-E. 1995. "Atmospheric Radionuclide Monitoring: A Swedish Perspective." In: Monitoring a Comprehensive Test Ban Treaty, eds. E S. Husebye and A.M. Dainty, pp. 157-177. NATO ASI Series E: Applied Sciences, Vol. 303, Kluwer Academic Publishers, Boston. 



\section{Contents}

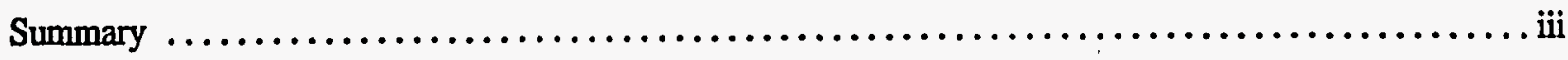

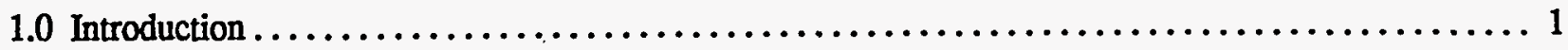

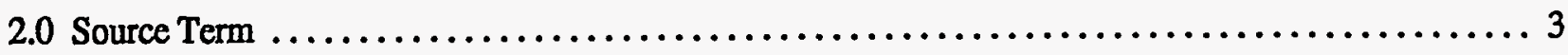

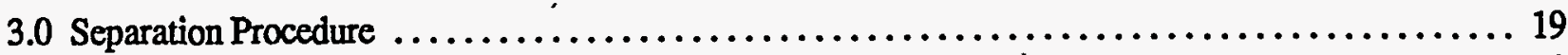

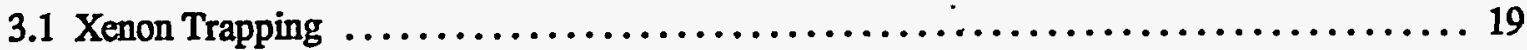

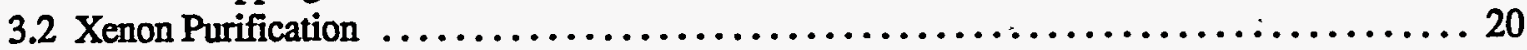

3.3 Xenon Quantification $\ldots \ldots \ldots \ldots \ldots \ldots \ldots \ldots \ldots \ldots \ldots \ldots \ldots \ldots \ldots \ldots \ldots \ldots \ldots \ldots \ldots \ldots, 21$

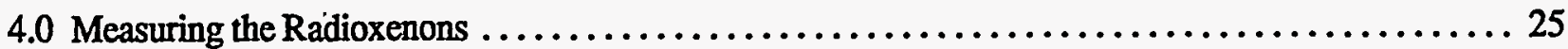

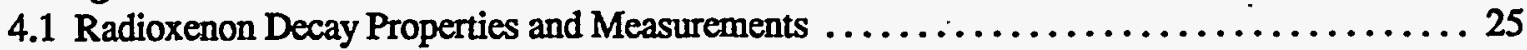

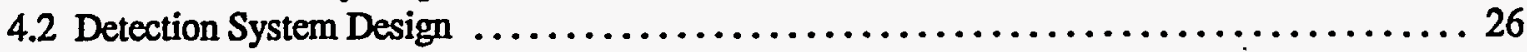

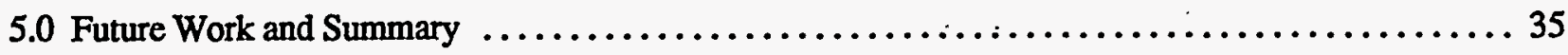

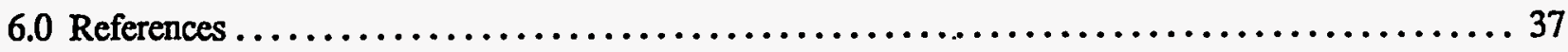

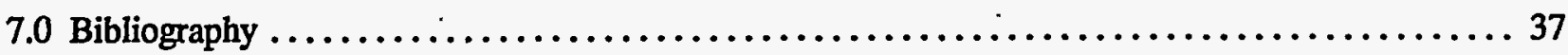

\section{Figures}

Figure 2.1. Independent and Chain Mass Yields for ${ }^{235} \mathrm{U}$ Fission and the Chains Leading to the Xenon Radionuclides ................................................. 6 Figure 2.2. Independent and Chain Mass Yields for ${ }^{239} \mathrm{Pu}$ Fission and the Chains Leading to the Xenons

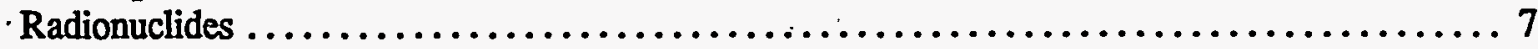

Figure 2.3. Xenon Radioactivity Levels Versus Time From a 1-Kiloton ${ }^{235} \mathrm{U}$ Blast in Which the Radioxenons Are Separated from Preceding Members of Their Mass Chain Within a Few Minutes of the

Detonation .................................................. 8

Figure 2.4. Xenon Radioactivity Levels Versus Time from a Promptly Vented, Underground 1-Kiloton ${ }^{239} \mathrm{Pu}$

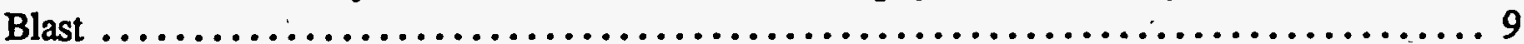

Figure 2.5. Xenon Radioactivity Levels Versus Time from a 1-Kiloton ${ }^{235} \mathrm{U}$ Atmospheric Blast ........ 10

Figure 2.6. Xenon Radioactivity Levels Versus Time from an Atmospheric 1-Kiloton ${ }^{239} \mathrm{Pu}$ Blast . ..... 11

Figure 2.7. Xenon Radioactivity Levels Versus Time Present in Commercial Nuclear Fuel $\left(3.5 \%{ }^{235} \mathrm{U}\right)$ after

Burnup of 20,000 Mega Watt Days/metric Ton of Uranium (MWd/MTU) Assuming a Neutron Flux

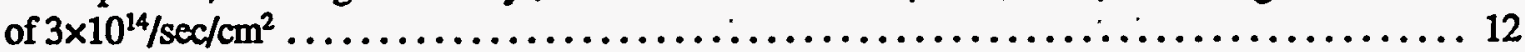

Figure 2.8. Xenon Radioactivity Levels Versus Time Present in Hanford Nuclear Fuel During ${ }^{239} \mathrm{Pu}$

Production for Nuclear Weapons Fabrication after Burnup of 728 MWd/MTU Assuming a Neutron

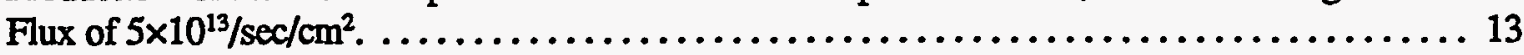

Figure 2.9. Xenon Radioactivity Levels Versus Time per cc of Xenon Produced by Irradiating Xenon Gas (In

Natural Isotopic Abundance) in a Triga Reactor with a Neutron Flux of $10^{13} / \mathrm{sec} / \mathrm{cm}^{2} . \ldots \ldots \ldots 14$

Figure 2.10. Variation of the Ratio of ${ }^{133 m} \mathrm{Xe}$ to ${ }^{133} \mathrm{Xe}$ Activity Levels Versus Time for a Prompt Vent of a

Nuclear Detonation and from Nuclear Reactor Effluent $\ldots \ldots \ldots \ldots \ldots \ldots \ldots \ldots \ldots \ldots \ldots$ 
Figure 2.11. Variation of the Ratio of ${ }^{135} \mathrm{Xe}$ to ${ }^{133} \mathrm{Xe}$ Activity Levels Versus Time for a Prompt Vent of a Nuclear Detonation and from Nuclear Reactor Effluent $\ldots \ldots \ldots \ldots \ldots \ldots \ldots \ldots \ldots \ldots \ldots$

Figure 3.1. Schematic Illustration of Radioxenon Sampler/Analyzer $\ldots \ldots \ldots \ldots \ldots \ldots \ldots \ldots \ldots \ldots 22$

Figure 3.2. Nuclear Level Diagram for the Radioxenons of Interest: a) $\left.{ }^{131 m} \mathrm{Xe}, \mathrm{b}\right){ }^{133} \mathrm{Xe}$ and ${ }^{133 m} \mathrm{Xe}$,

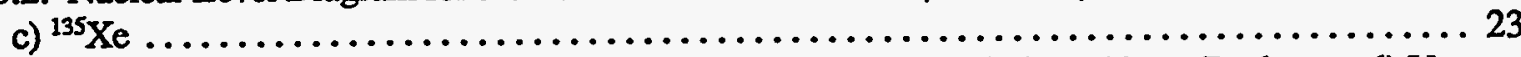

Figure 4.1. Xenon-133m Minimum Detectable Level (Two Standard Deviations Above Background) Versus Ambient Level of ${ }^{133} \mathrm{Xe}$, Dominated by the Uncertainty in the ${ }^{133} \mathrm{Xe}$ Level $\ldots \ldots \ldots \ldots \ldots \ldots 28$

Figure 4.2. Artist's Rendition of Two-Dimensional Energy-Energy Correlation for the Radioxenons of

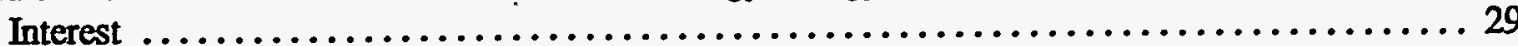

Figure 4.3. Schematic Illustration of Scintillating Gas-Cell Used for the Beta-Gamma Coincidence

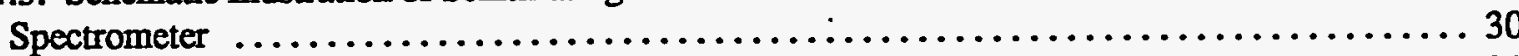

Figure 4.4. Improved NaI(Tl) Beta-gamma Coincidence Spectrometer . . . . . . . . . . . . . . 31

Figure 4.5. Gamma-Ray Spectrum Taken with Current NaI(Tl) Beta-Gamma Coincidence Spectrometer with

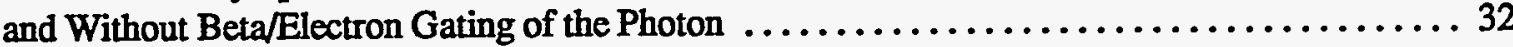

Figure 5.1. Cad Rendering of Engineering Field Model to Be Tested Starting in January, 1997 . . . . . . . 36

\section{Tables}

Table 2.1 Comparison of Xenon Radionuclide Activity Ratios Following 1-Kiloton Detonations (Chain

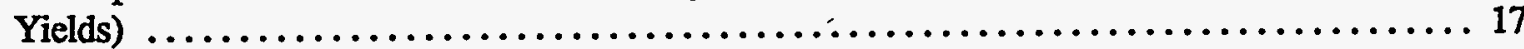

Table 4.1 Principle Emissions of the Radioxenons . ................................ 33 


\subsection{Introduction}

To help ensure compliance with a Comprehensive nuclear Test Ban Treaty (CTBT), it is important that monitoring technologies for detecting covert nuclear testing be available. Monitoring methods being developed and/or enhanced by the U.S. Department Of Energy (DOE) include seismic, hydroacoustics, infrasound, and radionuclide technologies. While seismic, hydroacoustic, and infrasound signals may provide evidence that an event has occurred, only detection of short-lived fission products can provide absolute confirmation that the event was a nuclear explosion. If evaders of a CTBT were to test a nuclear device covertly, they might attempt to carry it out in a manner that minimizes signatures associated with such an event. For example, conducting a test underground, underwater, or over the ocean in a rainstorm could minimize or eliminate some signatures, including the emission of particulate radionuclides. Under such conditions, only the gaseous radionuclides would enter the atmosphere in significant quantities, and in particular, the inert properties of the noble gases make them the most likely to enter the atmosphere in significant quantities. Of the noble gas radionuclides, the xenon radionuclides are by far the most abundant at a few days after a detonation. Therefore, detecting xenon radionuclides could provide confirmation that an event detected by another monitoring technology was a nuclear event, or, without other information, the event could be detected independently.

Staff at Pacific Northwest National Laboratory ${ }^{(a)}$ have spent 3 years developing and demonstrating a fully automatic analyzer for collecting and measuring the four xenon radionuclides, ${ }^{131 m} \mathrm{Xe}(11.9 \mathrm{~d}),{ }^{133 m \mathrm{Xe}}$ $(2.19 \mathrm{~d}),{ }^{133} \mathrm{Xe}(5.24 \mathrm{~d})$, and ${ }^{135} \mathrm{Xe}(9.10 \mathrm{~h})$, in the atmosphere. This work was funded and directed under DOE's NN-20 Comprehensive Test Ban Treaty Research and Development program.

(a) Pacific Northwest National Laboratory is operated for the U.S. Department of Energy by Battelle under Contract DE-ACO6-76RLO 1830. 



\subsection{Source Term}

Although the quantity of xenon radionuclides entering the atmosphere from a nuclear detonation may be very large, the combination of dilution in the atmosphere plus radioactive decay requires very sensitive measurements to detect these radionuclides. Furthermore, a radioactive plume might pass at a monitoring site in just a few hours, and therefore short collection periods with immediate purification and analysis are required to maximize signal-to-background ratios. Additionally, measuring the short-lived (9.10- $\mathrm{h}$ half-life) ${ }^{135} \mathrm{Xe}$, an important signature in differentiating radioxenon originating from nuclear detonations from those from other sources (see below), dictates the need for short collection periods.

Xenon radionuclides enter the atmosphere from sources other than nuclear detonations, including operating nuclear reactors and, to a lesser extent, from producing and using medical isotopes. They may also enter the atmosphere from nuclear fuel reprocessing if the delay between irradiation and reprocessing is not sufficient to permit complete decay of the radionuclides. Since the activity ratios of the xenon radionuclides vary greatly depending on the source, it is possible to determine the mechanism for producing these radionuclides, and hence their origin.

If a nuclear test were conducted in the atmosphere, the full spectrum of fission products would be released and become airborne. Such a detonation may most easily be detected and/or confirmed by collecting and analyzing particulate radionuclides. If a detonation were conducted in a manner to preclude or minimize particulate radionuclide release, however, noble gases may be the only fission products released into the atmosphere in significant quantities. Analyzing four xenon radionuclides is especially important in determining whether a detonation has taken place: ${ }^{131 \mathrm{~m}} \mathrm{Xe}(11.9 \mathrm{~d}),{ }^{133_{\mathrm{m}} \mathrm{Xe}}(2.19 \mathrm{~d}),{ }^{133} \mathrm{Xe}(5.24 \mathrm{~d})$, and ${ }^{135} \mathrm{Xe}$ $(9.10 \mathrm{~h})$. The activity ratios of these are unique for a nuclear detonation, and therefore their measurement can provide a basis for verification/dismissal of a suspected nuclear test. To illustrate how a covert nuclear weapons test can be distinguished from that originating from other sources by measuring xenon radionuclide activity ratios, expected xenon radionuclide concentrations and ratios from various sources are shown in Figures 2.1 through 2.11 .

Shown in Figures 2.1 and 2.2 are the independent fission yields (mass yields) (Thara 1989) of the four xenon radionuclides and their precursors that would result from ${ }^{235} \mathrm{U}$ and ${ }^{239} \mathrm{Pu}$ fission, respectively. If noble gases are either promptly vented from a nuclear test or vented within a few minutes, only the independent fission yields would contribute to the radioxenon released into the atmosphere. Therefore, the activity ratios for a prompt noble gas vent would be far different from those that could result from the cumulative chain yields ${ }^{(\mathbf{})}$.

Figures 2.3 through 2.11 illustrate the activity levels of the radioxenons versus time from several sources. These calculations were performed using the ORIGEN2 code (Perkins and Jenquin 1994).

Figures 2.3 and 2.4 show the temporal variation of the activity levels of the xenon radionuclides that are directly produced in 1-kiloton ${ }^{235} \mathrm{U}$ and ${ }^{239} \mathrm{Pu}$ nuclear detonations. Cumulative (or chain) yields from parents are excluded, and therefore these are the activity levels one might expect from a prompt vent of an underground nuclear detonation. The concentrations are determined from the independent fission yields of each radionuclide. Little ${ }^{131 \mathrm{~m} X e}$ is present; at production, the amount of the ${ }^{135} \mathrm{Xe}$ (including in-growth from ${ }^{135 m \mathrm{Xe}}$ [15.3 min] ) is several hundred times greater than ${ }^{133} \mathrm{Xe}$ or ${ }^{133 m} \mathrm{Xe}$, and the ${ }^{133 m \mathrm{Xe}}$ level is almost a factor of ten greater than ${ }^{133} \mathrm{Xe}$ for both ${ }^{235} \mathrm{U}$ and ${ }^{239} \mathrm{Pu}$ fission. Since the ${ }^{135} \mathrm{Xe}$ to ${ }^{133} \mathrm{Xe}$ activity ratio is about a factor of two higher for ${ }^{235} \mathrm{U}$ fission than for ${ }^{239} \mathrm{Pu}$ fission, if the time of a detonation were known and if

(a) Cumulative yields occur from all preceding members of a mass chain decay into the isotope of interest. 
venting occurred during the first several minutes, a subsequent measurement of the ${ }^{135} \mathrm{Xe}$ to ${ }^{133} \mathrm{Xe}$ activity ratio may provide an indication of the type of the device. Radioxenon activity ratios and their significance in source term characterization are discussed in more detail below.

Figures 2.5 and 2.6 illustrate the expected abundances of the xenon radionuclides for cumulative chain yields from 1-kiloton ${ }^{235} \mathrm{U}$ and ${ }^{239} \mathrm{Pu}$ nuclear detonations. The activity levels shown in these figures might occur in an atmospheric detonation with no ground contact in which very fine particles were formed allowing all of the radioxenon daughters from decay of their precursors to enter the atmosphere.

Figure 2.7 illustrates the concentrations of the xenon radionuclides in commercial power reactor fuel $\left(3.5 \%{ }^{235} \mathrm{U}\right)$ if released after continuous irradiation to a burn up of $20,000 \mathrm{MWd} / \mathrm{MTU}$ with a neutron flux of approximately $3 \times 10^{14} / \mathrm{sec} / \mathrm{cm}^{2}$. These data suggest that it might be possible to observe ${ }^{135} \mathrm{Xe}$ near a reactor, though we have not yet accomplished this. It appears that reactor containment systems have sufficient hold up, at least in the Northeast United States (Bowyer et al. 1996), to allow most of the ${ }^{135} \mathrm{Xe}$ to decay before release.

Figure 2.8 shows the quantities of the xenon radionuclides in Hanford fuel during ${ }^{239} \mathrm{Pu}$ production for nuclear weapons fabrication as a function of time after irradiation. The concentrations are those that would be in the fuel after continuous irradiation with a nominal neutron flux of $5 \times 10^{13} / \mathrm{sec} / \mathrm{cm}^{2}$, to an exposure level of $728 \mathrm{MWd} / \mathrm{MTU}$, typical for Hanford fuel (Perkins and Jenquin 1994). These data provide a comparison of the ratios expected from nuclear power production versus various nuclear fuel decay periods before reprocessing. It is clear that ${ }^{131 m X e}$ and ${ }^{133} \mathrm{Xe}$ are the most abundant of the radioxenons after 10 days, and they have equal activities after about 60 days. Also, ${ }^{131 m} \mathrm{Xe}$ is the only radionuclide with a significant activity level 120 days post irradiation. However, if fuel reprocessing were delayed for 1 year or more after irradiation, even the ${ }^{131 \mathrm{~m}} \mathrm{Xe}$ activity would have decayed to an insignificant level. While activity ratios of the xenon radionuclides are essentially the same in plutonium production and commercial power fuels, the concentrations are much higher in the commercial fuel for the exposures stated because of the longer exposure time and higher neutron flux.

Producing and using medical isotopes could produce a significant amount of xenon radionuclides; however, this would normally be of little consequence in a CTBT monitoring program unless a monitoring station were located very near a production/processing or medical isotope usage facility, or an accidental massive release were to take place. Figure 2.9 illustrates the concentrations of the xenon radionuclides that would be produced by irradiation of stable xenon (in atmospheric isotopic ratios) in a Triga reactor for a 10-day period. A typical Triga reactor provides a thermal neutron flux of $10^{13} / \mathrm{sec} / \mathrm{cm}^{2}$ or more. In this process, the main products are ${ }^{131 m} \mathrm{Xe}$ and ${ }^{133} \mathrm{Xe}$ at a few days post irradiation. Since the medical-related . xenon radionuclide activity ratios are very different from those that would be vented from an underground nuclear detonation, and the total radioxenon emission from medical applications is normally small, this source should not be a significant interference in monitoring for nuclear detonations unless a monitoring site were located near a production or usage facility.

Table 2.1 summarizes the ratios between the xenon radionuclides that could vent from nuclear detonations. Even if substantial venting were to continue for minutes and the xenon radionuclides formed by ingrowth from precursors were vented with equal efficiency, their ratios would still provide conclusive evidence of the subsurface detonation. It is less likely that xenon radioisotopes produced by the decay of precursors will be vented. The energy of a detonation could cause much of the direct yield radioxenon to move rapidly to the surface and be released in a matter of minutes. The precursors, however, behave according to their chemical properties and could be retained in or near the molten earth material, leaving a lesser opportunity for their daughter radioxenons to escape. Therefore, if an evasion scenario were attempted 
where significant noble gas emission occurred, and particulate radionuclide release was minimal, measuring atmospheric xenon radionuclides could confirm that the radioxenon was from a nuclear detonation.

To further clarify the discrimination capability provided by radioxenon ratios in differentiating between nuclear detonation sources and reactor sources, Figures 2.10 and 2.11 compare the ratios of the ${ }^{133 m X e}$ to ${ }^{133} \mathrm{Xe}$ isomers and ${ }^{135} \mathrm{Xe}$ to ${ }^{133} \mathrm{Xe}$ versus time after release. The ${ }^{133} \mathrm{Xe}$ isomer ratio should permit radioxenon derived from a nuclear reactor to be distinguished from reactor emissions over periods of 10 to 15 days post detonation while the ${ }^{135} \mathrm{Xe}$ to ${ }^{133} \mathrm{Xe}$ ratio should allow this selective discrimination over periods of up to 4 or 5 days post detonation for both ${ }^{235} \mathrm{U}$ and ${ }^{239} \mathrm{Pu}$ weapons.

Based on the data presented in Figures 2.1 through 2.11, Table 2.1, and associated discussions, it can be concluded that 1) medical isotope production/usage should contribute relatively small amounts of radioxenon, and the radionuclide ratios from this source can be distinguished from those resulting from nuclear detonations, 2) nuclear fuel reprocessing, even after short decay periods, would have xenon radioisotope activity ratios that can be distinguished from those from nuclear detonations, and after a 1-year decay period, releases would be negligible, and 3) the radioxenon activity ratios from operating commercial power reactors emissions are different from nuclear detonations. Nuclear power plants do, however, provide a major source of atmospheric ${ }^{133} \mathrm{Xe}$, and this background could limit the sensitivity for detection of nuclear-weapons-associated radioxenon in areas of the world where many reactors are operating. 

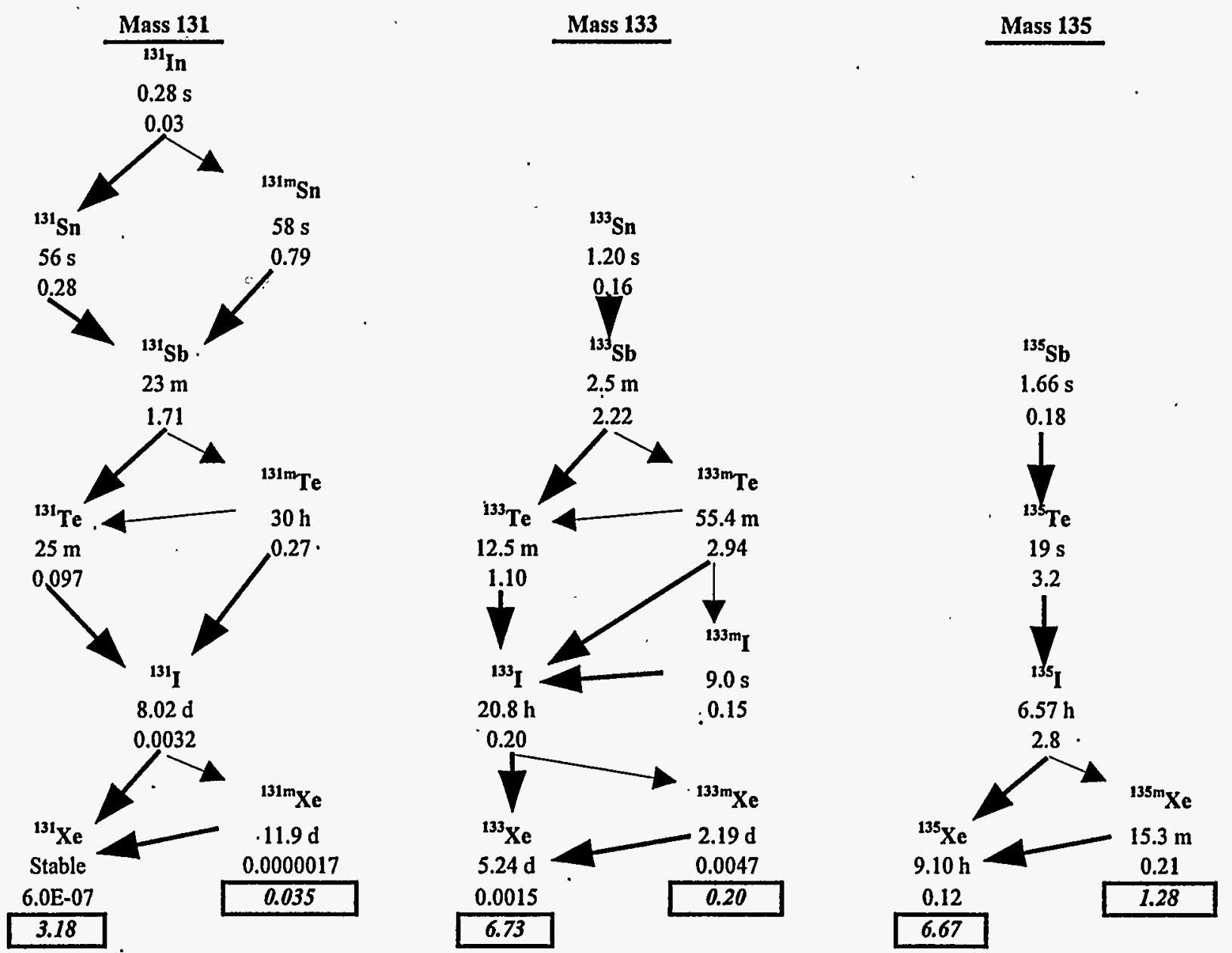

Figure 2.1. Independent and Chain Mass Yields for ${ }^{235} \mathrm{U}$ Fission and the Chains Leading to the Xenon Radionuclides. The half-lives are shown below the radionuclide, the independent yields (indicating the amount produced directly in nuclear detonation) are shown below the half-lives, and the boxed italics-font represent the chain yields (indicating the amount produced from precursors in addition to independent yield). The yields are in percent of total fissions. 

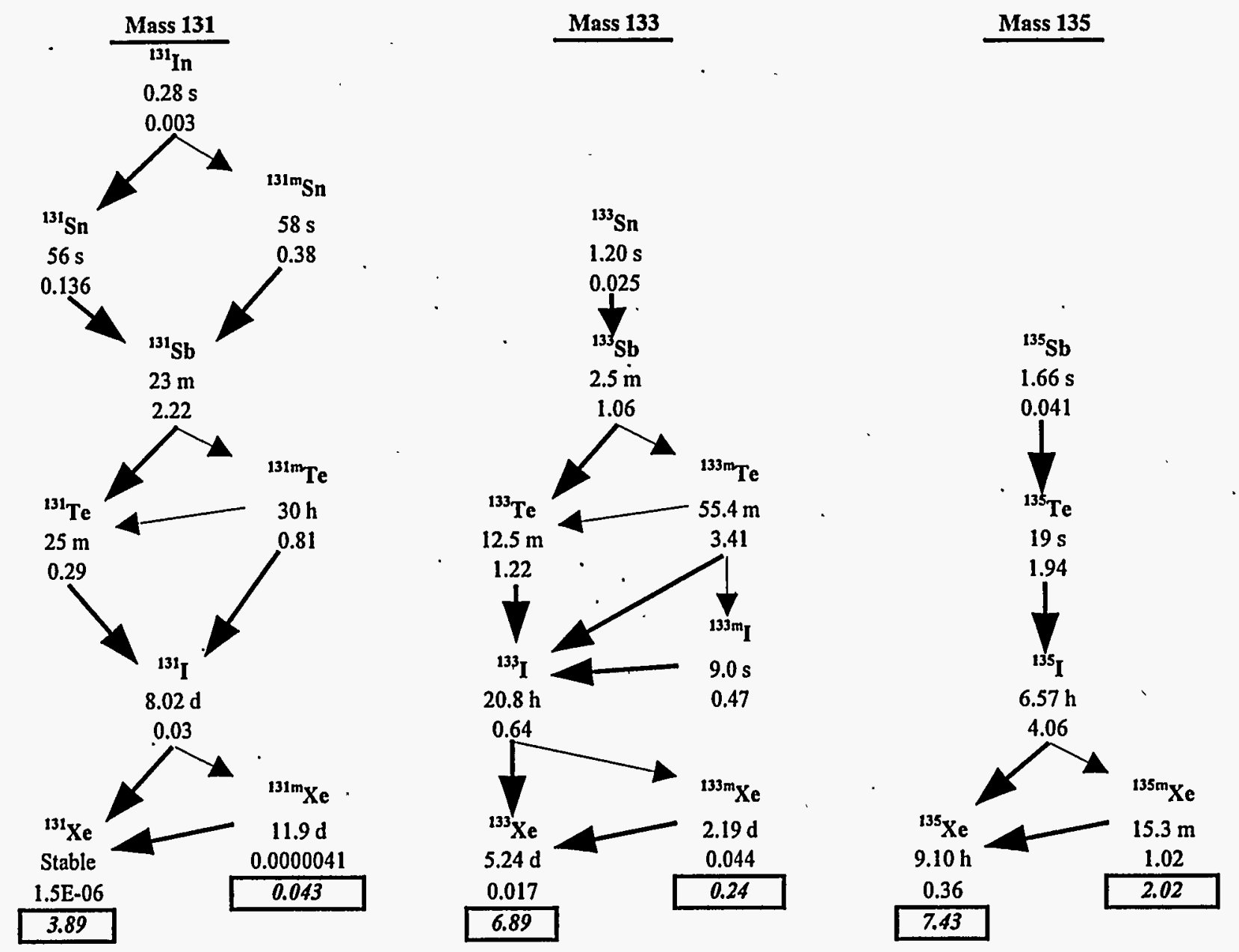

Figure 2.2. Independent and Chain Mass Yields for ${ }^{239} \mathrm{Pu}$ Fission and the Chains Leading to the Xenons Radionuclides. The half-lives are shown below the radionuclide, the independent yields are shown below the half-lives, and the boxed italics-font represent the chain yields. The yields are in percent of total fissions. 


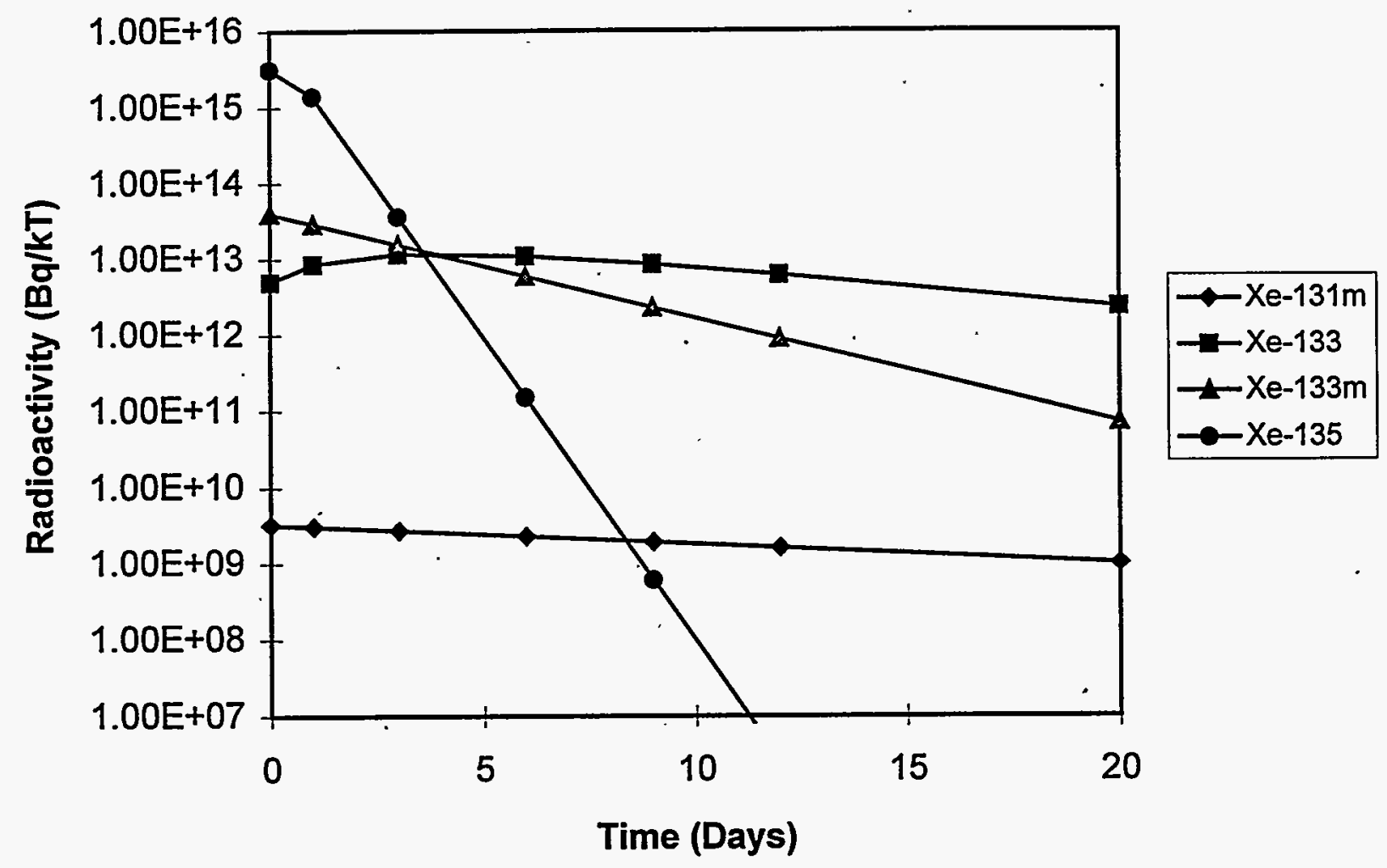

Figure 2.3. Xenon Radioactivity Levels Versus Time From a 1-Kiloton ${ }^{235}$ U Blast in Which the Radioxenons Are Separated from Preceding Members of Their Mass Chain Within a Few Minutes of the Detonation. Contribution to the radioxenon activity levels come only from the directly produced fission yield-this is also called independent yields and also "prompt venting" from an underground blast. 


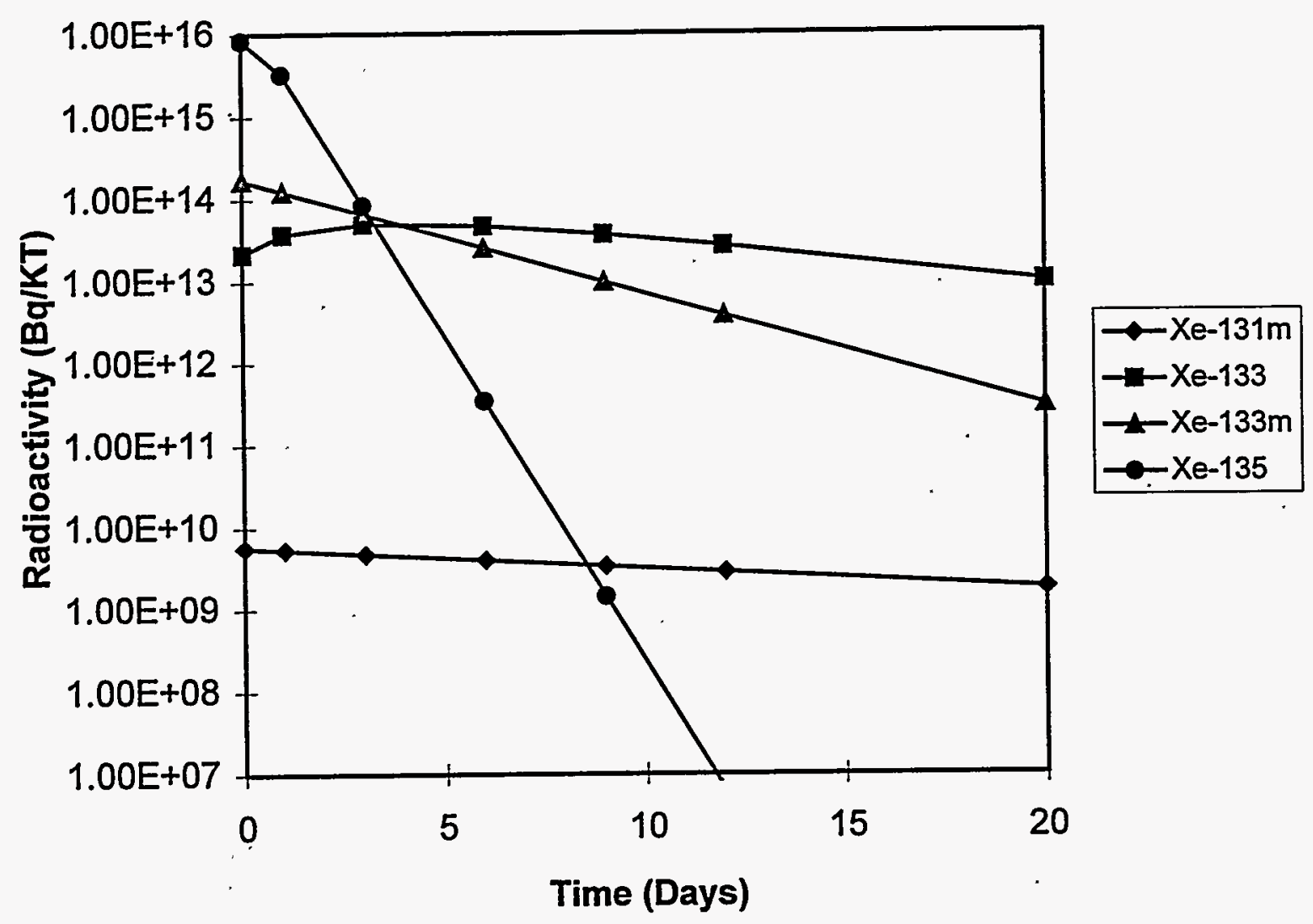

Figure 2.4. Xenon Radioactivity Levels Versus Time from a Promptly Vented, Underground 1-Kiloton ${ }^{239} \mathrm{Pu}$ Blast 


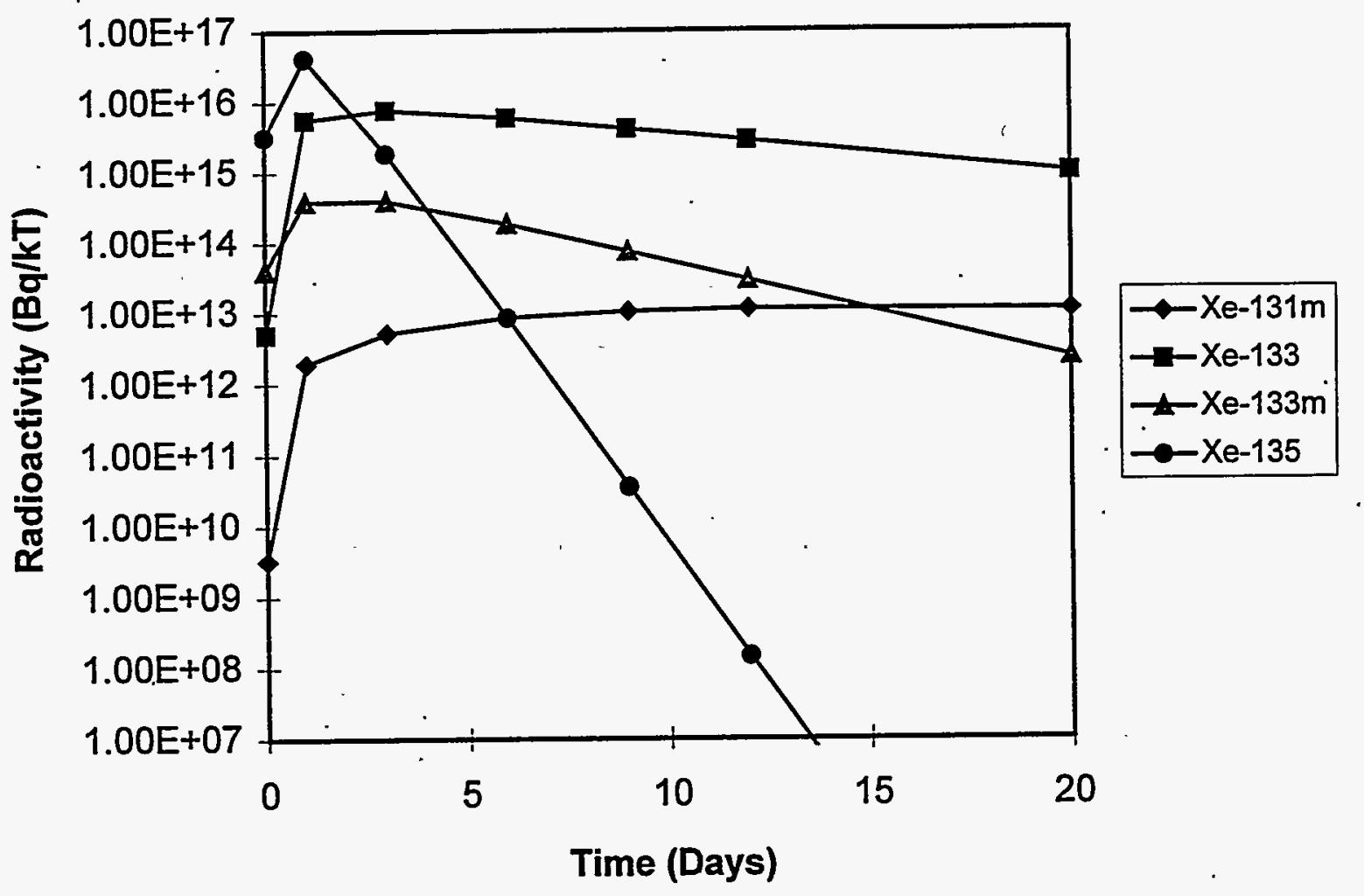

Figure 2.5. Xenon Radioactivity Levels Versus Time from a 1-Kiloton ${ }^{235} \mathrm{U}$ Atmospheric Blast. The radioxenons that are directly produced are not separated from their parent isotopes; therefore, they are fed by the isotopes in their mass chain. Consequently, the activity levels are higher than for independent yields. This is also called chain or cumulative yields. 


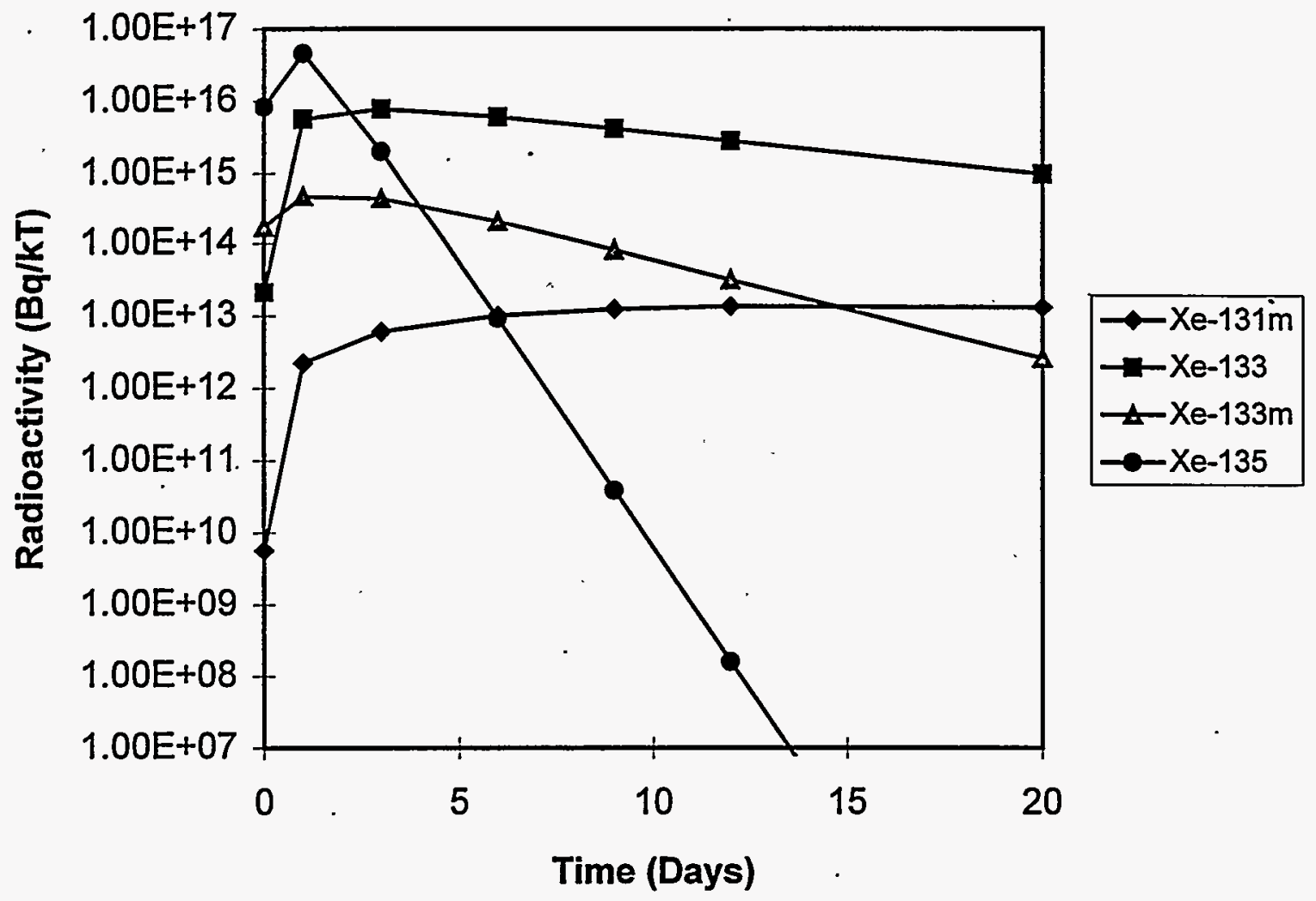

Figure 2.6. Xenon Radioactivity Levels Versus Time from an Atmospheric 1-Kiloton ${ }^{239} \mathrm{Pu}$ Blast 


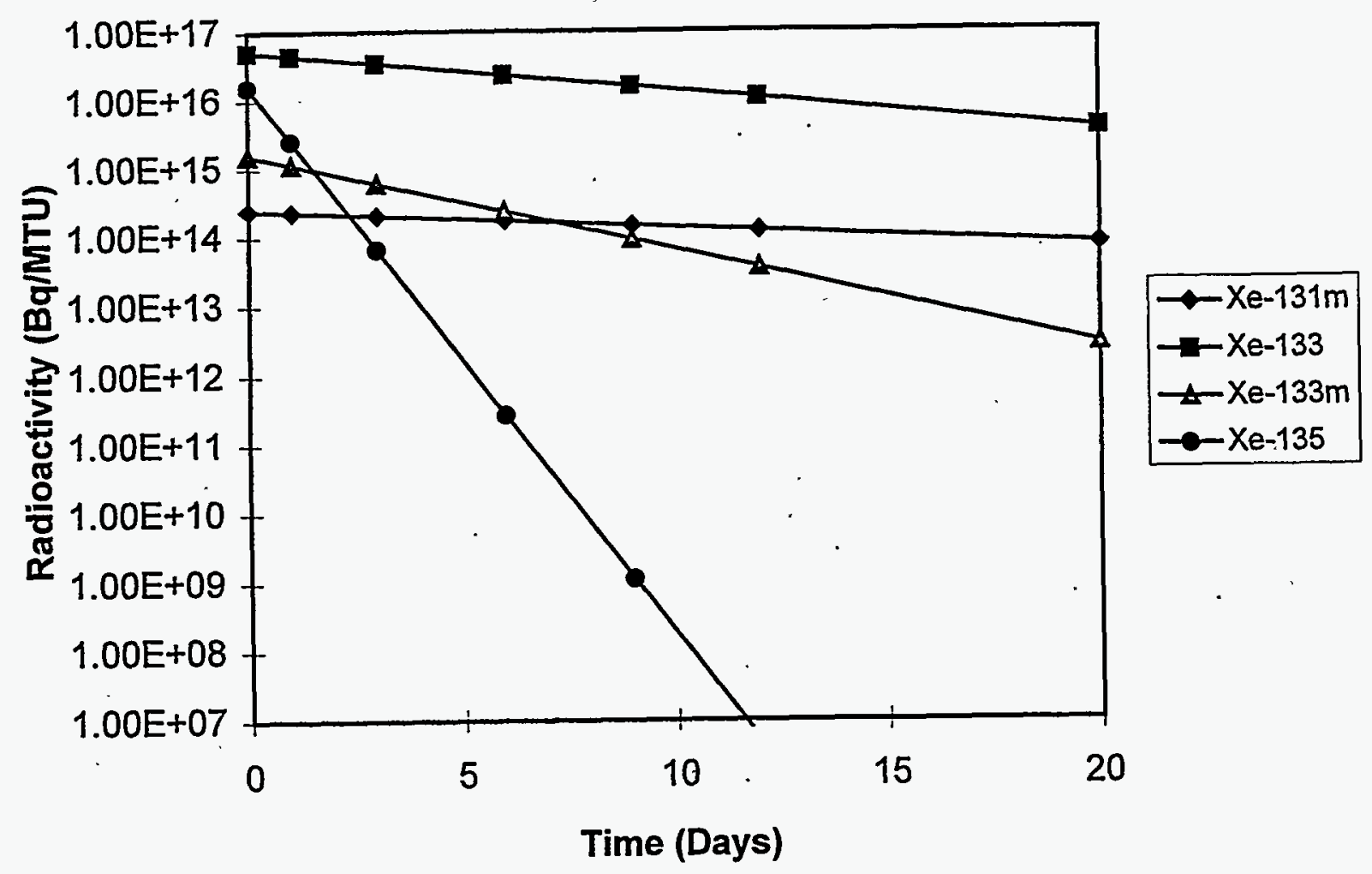

Figure 2.7. Xenon Radioactivity Levels Versus Time Present in Commercial Nuclear Fuel $\left(3.5 \%{ }^{235} \mathrm{U}\right)$ after Burnup of 20,000 Mega Watt Days/metric Ton of Uranium (MWd/MTU) Assuming a Neutron Flux of $3\left(10^{14}\right) / \mathrm{sec} / \mathrm{cm}^{2}$. This exposure is approximately one-half to two-thirds of the useful life of a commercial nuclear reactor. 


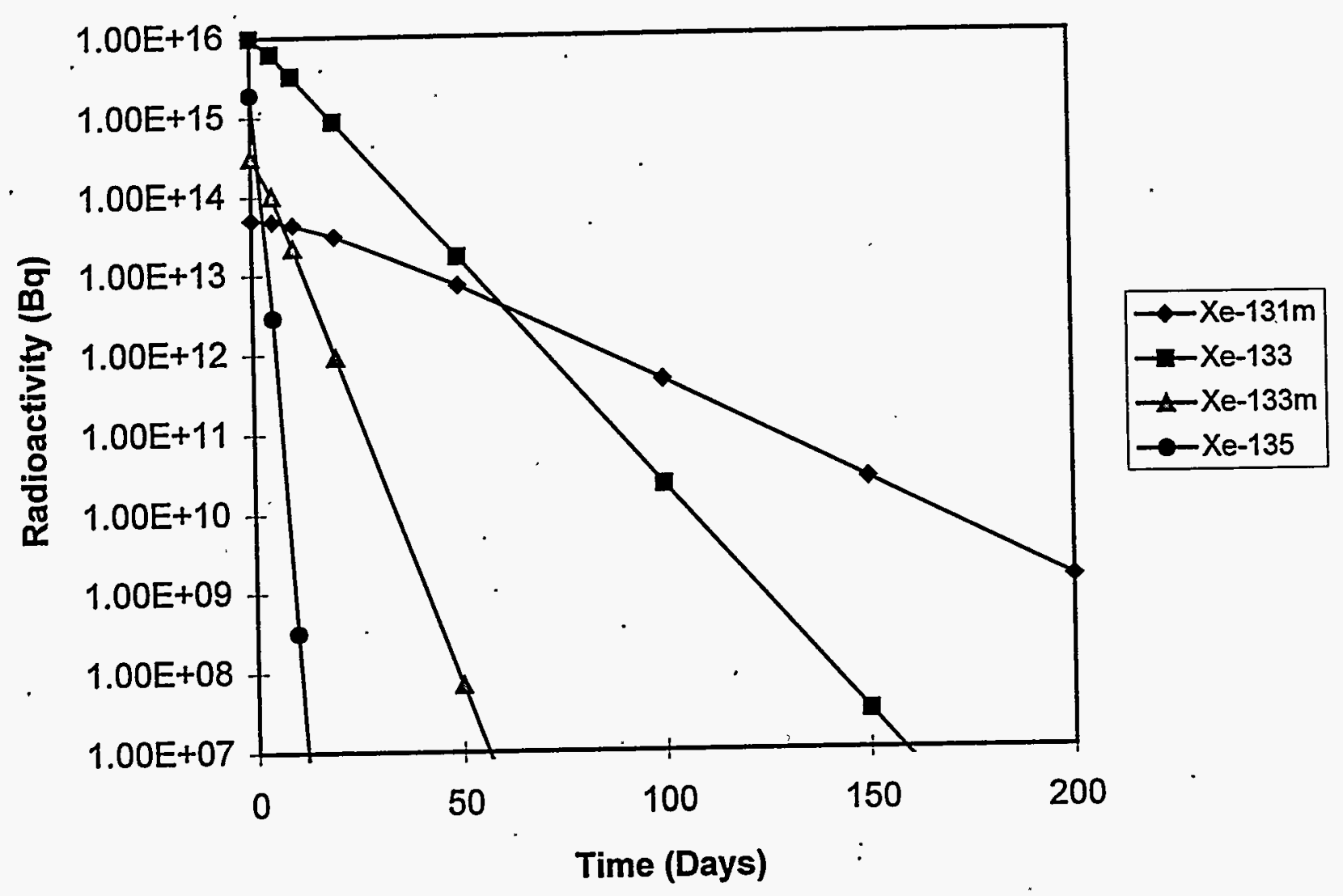

Figure 2.8. Xenon Radioactivity Levels Versus Time Present in Hanford Nuclear Fuel During ${ }^{239} \mathrm{Pu}$ Production for Nuclear Weapons Fabrication after Burnup of 728 MWd/MTU Assuming a Neutron Flux of $5 \times 10^{13} / \mathrm{sec} / \mathrm{cm}^{2}$. This is the average exposure (Perkins and Jenquin 1994) typical for ${ }^{239} \mathrm{Pu}$ production at Hanford. 


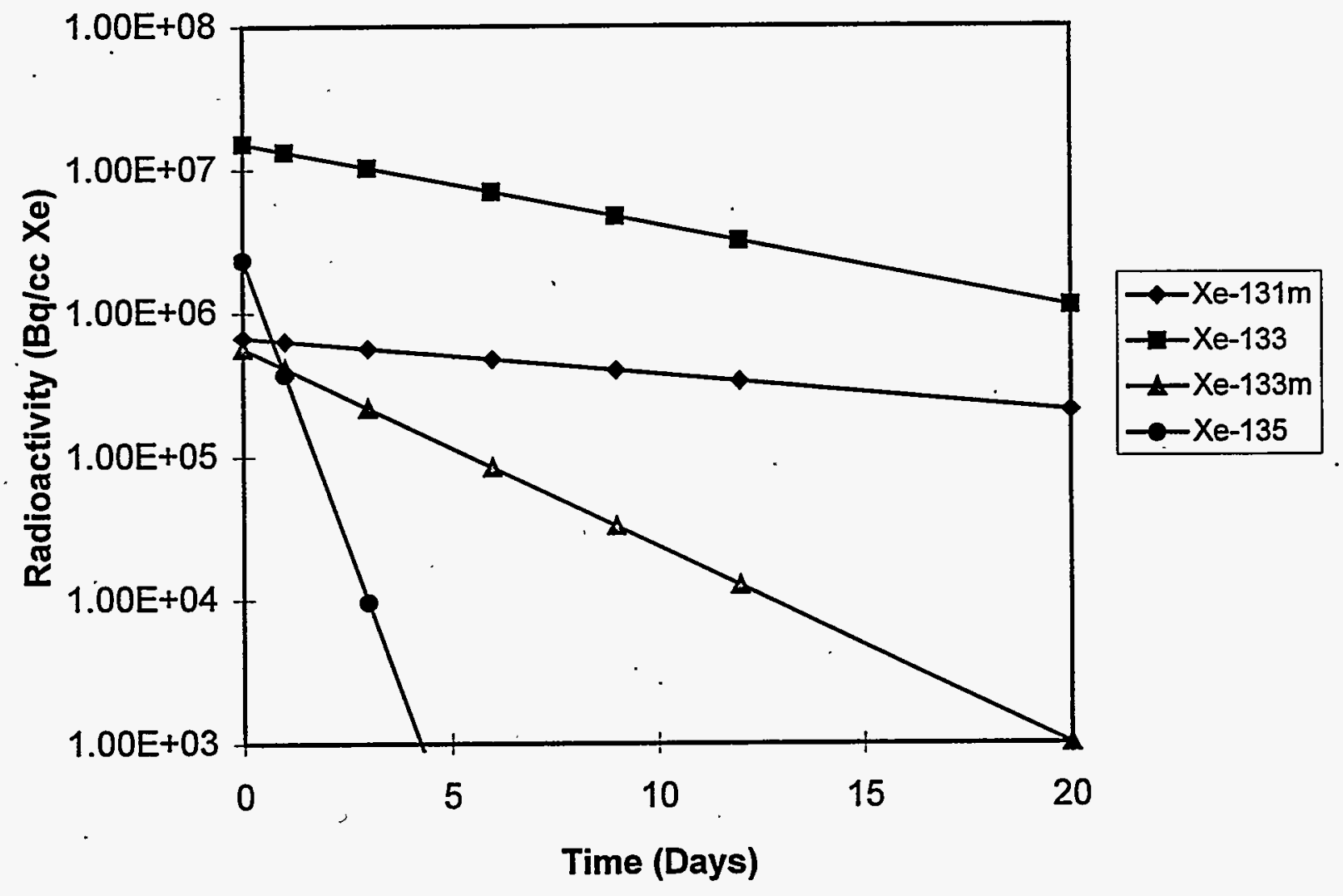

Figure 2.9. Xenon Radioactivity Levels Versus Time per $c c$ of Xenon Produced by Iradiating Xenon Gas (In Natural Isotopic Abundance) in a Triga Reactor with a Neutron Flux of $10^{13} / \mathrm{sec} / \mathrm{cm}^{2}$. This is a procedure used to produced radioxenon for medical diagnostics. 


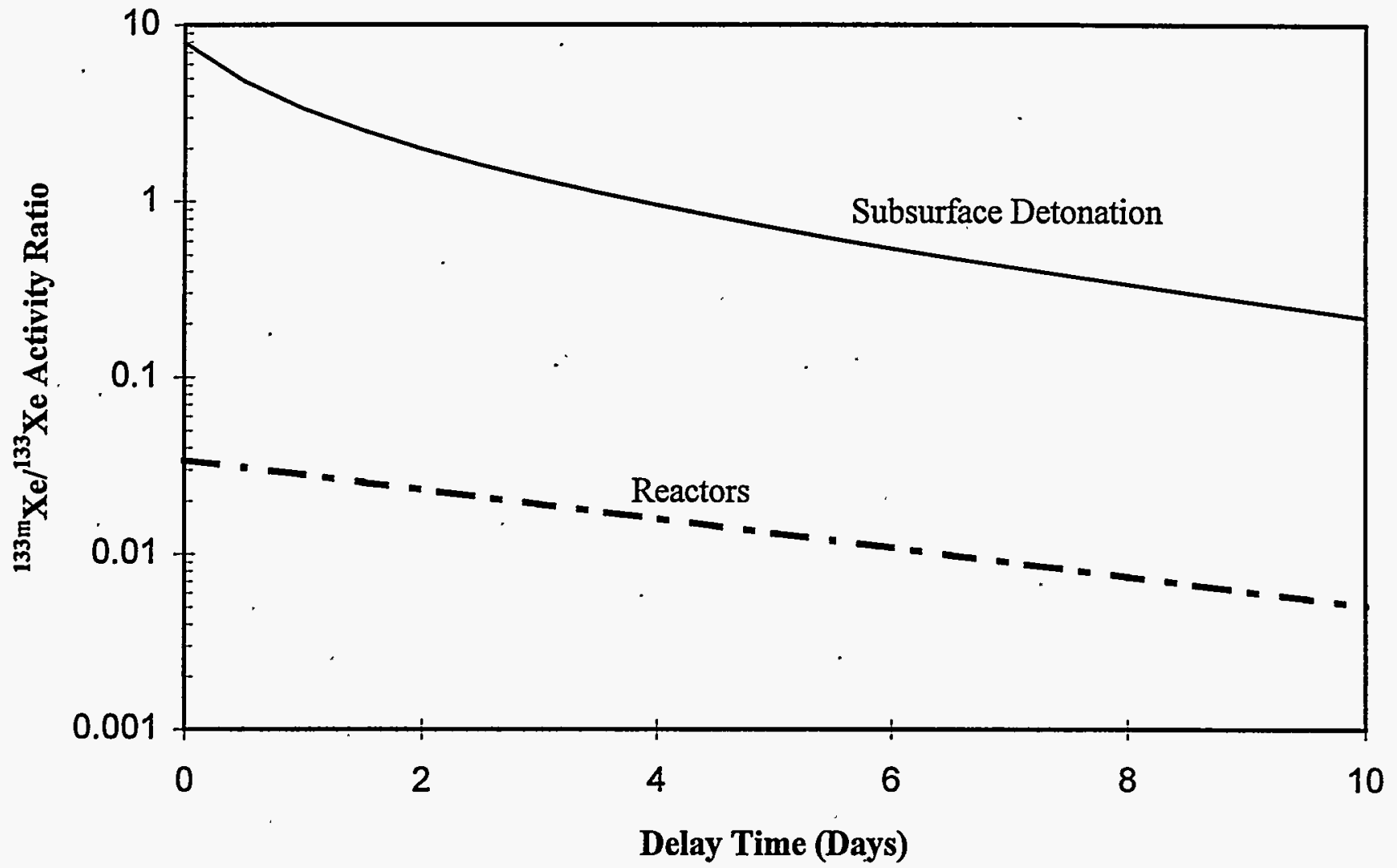

Figure 2.10. Variation of the Ratio of ${ }^{133 m} \mathrm{Xe}$ to ${ }^{133} \mathrm{Xe}$ Activity Levels Versus Time for a Prompt Vent of a Nuclear Detonation and from Nuclear Reactor Effluent. Discrimination between reactors and nuclear blasts is possible for up to 10 to 15 days post detonation. 


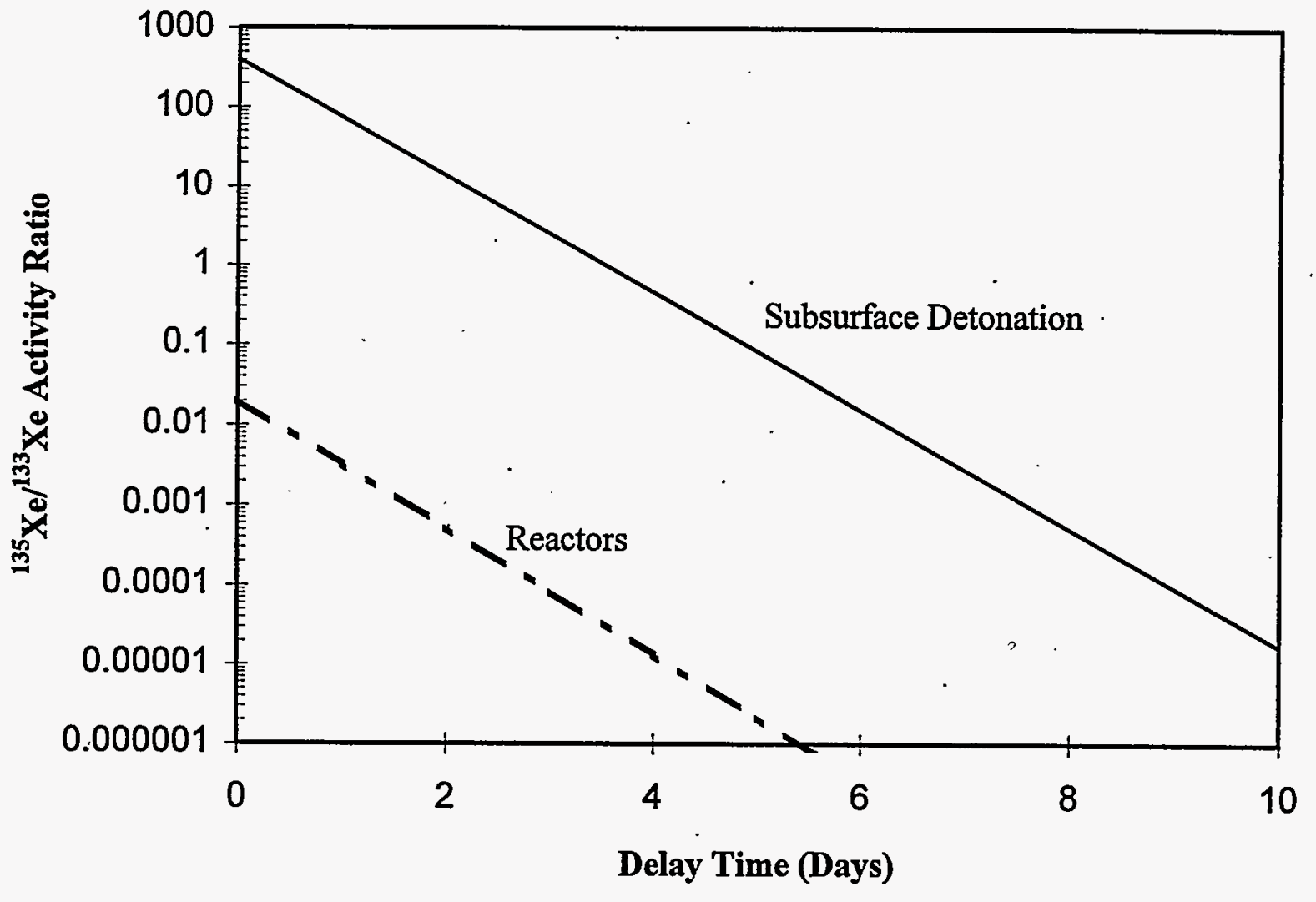

Figure 2.11. Variation of the Ratio of ${ }^{135} \mathrm{Xe}$ to ${ }^{133} \mathrm{Xe}$ Activity Levels Versus Time for a Prompt Vent of a Nuclear Detonation and from Nuclear Reactor Effluent. Discrimination between reactors and nuclear blasts is possible for up to 4 to 5 days post detonation. 
Table 2.1 Comparison of Xenon Radionuclide Activity Ratios Following 1-Kiloton Detonations (Chain Yields)

\begin{tabular}{|c|c|c|c|}
\hline Radionuclide Ratio & Time after detonation & ${ }^{235} \mathrm{U}$ & ${ }^{239} \mathbf{P u}$ \\
\hline \multirow[t]{9}{*}{${ }^{135} \mathrm{Xe} /{ }^{133} \mathrm{Xe}$} & $0 \mathrm{~min}$ & 640.1 & 388.3 \\
\hline & $2 \mathrm{~min}$ & 688.5 & 419.5 \\
\hline & $5 \mathrm{~min}$ & 639.8 & 435.8 \\
\hline & $10 \mathrm{~min}$ & 467.5 & 408.8 \\
\hline & $30 \mathrm{~min}$ & 183 & 239.3 \\
\hline & $2 \mathrm{hr}$ & 62.5 & 81.3 \\
\hline & $5 \mathrm{hr}$ & 36.6 & 43.3 \\
\hline & $10 \mathrm{hr}$ & 22.7 & 25.6 \\
\hline & $20 \mathrm{hr}$ & 10.5 & 11.5 \\
\hline \multirow[t]{9}{*}{${ }^{133 \mathrm{~m}} \mathrm{Xe} /{ }^{133} \mathrm{Xe}$} & $0 \mathrm{~min}$ & 7.92 & 7.85 \\
\hline & $2 \mathrm{~min}$ & 6.8 & 7.28 \\
\hline & $5 \mathrm{~min}$ & 4.86 & 6.3 \\
\hline & $10 \mathrm{~min}$ & 2.64 & 4.74 \\
\hline & $30 \mathrm{~min}$ & 0.61 & 1.79 \\
\hline & $2 \mathrm{hr}$ & 0.15 & 0.38 \\
\hline & $5 \mathrm{hr}$ & 0.096 & 0.179 \\
\hline & $10 \mathrm{hr}$ & 0.081 & 0.121 \\
\hline & $20 \mathrm{hr}$ & 0.072 & 0.092 \\
\hline \multirow[t]{9}{*}{${ }^{131 \mathrm{~m}} \mathrm{Xe} /{ }^{133} \mathrm{Xe}$} & $0 \mathrm{~min}$ & $6.49 \mathrm{E}-04$ & 2.63E-04 \\
\hline & $2 \mathrm{~min}$ & $5.59 \mathrm{E}-04$ & 2.45E-04 \\
\hline & $5 \mathrm{~min}$ & $4.04 \mathrm{E}-04$ & 2.15E-04 \\
\hline & $10 \mathrm{~min}$ & 2.32E-04 & $1.71 \mathrm{E}-04$ \\
\hline & $30 \mathrm{~min}$ & $1.00 \mathrm{E}-04$ & $1.14 \mathrm{E}-04$ \\
\hline & $2 \mathrm{hr}$ & $1.69 \mathrm{E}-04$ & $1.94 \mathrm{E}-04$ \\
\hline & $5 \mathrm{hr}$ & $2.30 \mathrm{E}-04$ & 2.63E-04 \\
\hline & $10 \mathrm{hr}$ & $2.66 \mathrm{E}-04$ & $3.04 \mathrm{E}-04$ \\
\hline & $20 \mathrm{hr}$ & $3.22 \mathrm{E}-04$ & $3.69 \mathrm{E}-04$ \\
\hline
\end{tabular}





\subsection{Separation Procedure}

To achieve maximum sensitivity in a practical, automatic radioxenon analyzer system, it was necessary to 1) sample xenon from the atmosphere at as high a rate as feasible, 2) employ a high-efficiency detector system capable of measuring all of the airborne radioxenons simultaneously, 3) minimize background count rate, 4) completely eliminate radon in the separated xenon samples, 5) conduct short cycles of continuous separations with prompt subsequent analysis of the aliquots to provide timely reporting and avoid serious decay of the radioxenons (especially the $9.1-\mathrm{h}$ half-life ${ }^{135} \mathrm{Xe}$ ), and 6) permit continuous separation and analysis at a monitoring site without the need for an operator or frequent maintenance.

An essential requirement of the separation process is to totally separate the radon from the xenon gas product. The ambient atmospheric concentration of ${ }^{222} \mathrm{Rn}$ of about $10 \mathrm{~Bq} / \mathrm{m}^{3}$ is more than $10^{5}$ times greater than the desired detection sensitivity for ${ }^{133} \mathrm{Xe}$; therefore, it could cause a serious interference if it were not removed before analysis (Bowyer et al. 1996).

Atmospheric xenon is sampled and subsequently analyzed in three principal steps. First, xenon is adsorbed from a dried, nearly $\mathrm{CO}_{2}$-free air stream on a cooled, activated charcoal trap at a flow rate of about $7 \mathrm{~m}^{3} / \mathrm{h}$. Second, the xenon trapped on the charcoal bed is thermally desorbed, purified, and retrapped on another charcoal bed to remove traces of most of the remaining atmospheric gases, radon, and $\mathrm{CO}_{2}$. Third, the purified sample is transferred to a nuclear spectroscopy system, counted, and then assayed using a residual gas analyzer (quadrupole mass spectrometer), so the stable xenon concentration can be determined. Figure 3.1 shows a simplified schematic illustration of our xenon sampler/analyzer. The vertical dotted lines delineate the three steps used to trap, purify, and analyze the radioxenons. Much of the detail related to the duplicate pieces of hardware necessary for $100 \%$ duty cycle of this system have been left out of the figure.

\subsection{Xenon Trapping}

Xenon is very highly adsorbed on activated charcoal at low temperatures. We trap the xenon from a stream of compressed, dry, and nearly $\mathrm{CO}_{2}$-free air by passing it through a bed of cooled charcoal. Since the xenon adsorption capacity, $k$, on activated charcoal varies strongly with decreasing absolute temperature, $T$, as $\{k \sim \exp (1 / T)\}$ (Bolmsjo and Persson 1982), we have attempted to keep the temperature of the charcoal bed as low as currently feasible $\left(\mathrm{T}<-120^{\circ} \mathrm{C}\right)$ without using liquid nitrogen. In addition, to simplify the purification process (see Section 3.2), all of the water vapor and $\mathrm{CO}_{2}$ must be removed from the air stream. In the past, ambient levels of atmospheric radioxenons were generally measured by drying air followed by collections at temperatures of $-70^{\circ} \mathrm{C}$ to $-80^{\circ} \mathrm{C}$ on activated charcoal beds (Bernstrom et al. 1983; Kunz 1989; Kunz and Paperiello 1976; Kunz 1973; Pence et al. 1978) with flow rates on the order of 0.2 to $0.4 \mathrm{~m}^{3} / \mathrm{h}$.

An oil-less piston compressor (see Figure 3.1) (a) forces air at $~ 550$ to $700 \mathrm{kPa}$ ( 80 to $100 \mathrm{psig}$ ) at a rate of $\sim 7 \mathrm{~m}^{3} / \mathrm{h}$ through a particulate filter and a heat exchanger (b) which cools the air to about $25^{\circ} \mathrm{C}$, and moves it through a $100 \%$ duty cycle industrial air drying system (c) filled with a mixed bed of $13 \mathrm{X}$ molecular sieve and $\mathrm{Al}_{2} \mathrm{O}_{3}$, in a ratio of 2:1 (two columns approximately $150-\mathrm{cm}$ long by $10-\mathrm{cm}$ dia). In these drying units, the air stream first passes through the $\mathrm{Al}_{2} \mathrm{O}_{3}$, which is used to remove water vapor from the air stream, and then through the molecular sieve which is used to remove $\mathrm{CO}_{2}$. The total flow rate through the air drying units is monitored and kept constant through the use of a mass-flow controlling unit (d), just downstream of the air dryers. Each of the drying columns has enough capacity to remove $\mathrm{CO}_{2}$ and moisture from an air stream at a flow rate of $\sim 7 \mathrm{~m}^{3} / \mathrm{h}$ for approximately 5 hours before it must be regenerated. The dryers are regenerated by heating the adsorbents in the units internally to about $350^{\circ} \mathrm{C}$ and flowing dry, $\mathrm{CO}_{2}$-free air 
through it for approximately 4 hours. The "purge" air used to regenerate the dryers is fed from the output of the main charcoal trap.

After the dry air stream emerges from the air drying unit, it passes through a cryogenic air chiller (e) (PGC-150 from PolyCold). This air chiller is capable of lowering the output temperature of a room temperature air stream to about $-125^{\circ} \mathrm{C}$ at flow rates up to approximately $20 \mathrm{~m}^{3} / \mathrm{h}$. The cold airstream provides the cooling necessary for the "radon pre-trap" (f) and the main charcoal trap (g).

The 5-cm long by $1-\mathrm{cm}$ dia radon pre-trap is filled with activated charcoal and cooled to about $-125^{\circ} \mathrm{C}$ by the air stream from the chiller. This bed is used to eliminate much of the radon in the sampled air. Since the radon pretrap has a relatively small volume, the contact time with the air stream is very short, so xenon is not appreciably adsorbed. The radon, however, is adsorbed much more strongly than xenon on cooled charcoal, and hence a large amount of radon is retained on this trap. Since the radon pre-trap continually adsorbs radon throughout a run, it must be regenerated after each cycle. We have determined that a regeneration time of 2 hours at $\sim 300^{\circ} \mathrm{C}$ while under vacuum is sufficient to the regenerate this trap.

Detailed laboratory analyses with radioactive ${ }^{133} \mathrm{Xe}$ gas spikes have shown that with a $7 \mathrm{~m}^{3} / \mathrm{h}$ flow rate through the main charcoal trap $(\mathrm{g})\left(20-\mathrm{cm}\right.$ long by $10-\mathrm{cm}$ dia held at $\left.-125^{\circ} \mathrm{C}\right)$, the xenon is retained for approximately 6 hours before it begins to break through the bed. This corresponds to a total air sample volume of about $40 \mathrm{~m}^{3}$. Once the xenon has also been adsorbed by the charcoal at low temperatures, it remains adsorbed even at room temperatures for long periods (days).

Since the charcoal is held at a low temperature during the 6-hour trapping process, other atmospheric gases are also adsorbed on the charcoal. To remove as much of these lower boiling point gases (mostly $\mathrm{N}_{2}$, $\mathrm{O}_{2}$, and $\mathrm{Ar}$ ) as possible while not losing a significant amount of xenon, a vacuum is pulled $(\sim 100 \mathrm{~Pa})$ on the trap for approximately 30 minutes after completing the trapping step. Most of the xenon (>90\%) is retained on the charcoal bed even after the vacuum has been pulled on the trap.

\subsection{Xenon Purification}

The xenon is desorbed from the charcoal trap ( $\mathrm{g}$ ) and directed through the rest of the purification process by heating and purging with a nitrogen carrier gas $(\mathrm{h})$ maintained at $-200 \mathrm{cc} / \mathrm{min}$ with mass flow controllers (i-j). To facilitate xenon desorption, internal heaters are used to increase the temperature of the charcoal in the trap to $\sim 300^{\circ} \mathrm{C}$, while the nitrogen flows through the trap. Further heating of the charcoal trap $(\mathrm{g})$ under vacuum for several hours is used to regenerate it.

A series of three additional traps $(k-m)$ is used for further purification and to facilitate the transfer of the xenon into the counting system. These traps are regenerated in the same way as the main charcoal trap (g). The first $25-\mathrm{cm}$ long by $10-\mathrm{cm}$ dia trap $(\mathrm{k})$ after the main charcoal trap contains a mixture of ascarite and silica gel $\left(71 \%\right.$ ascarite $-29 \%$ silica gel). This trap removes any traces of $\mathrm{CO}_{2}$ that may not have been adsorbed by the drying columns (c), or adsorbed in the post-radon trap (f). The silica gel is used to remove $\mathrm{H}_{2} \mathrm{O}$ produced in the reaction that removes the $\mathrm{CO}_{2}$. This trap can remove $>0.07 \mathrm{~m}^{3}$.at standard temperature and pressure (STP) of $\mathrm{CO}_{2}$.

The second of the purification traps (1) is $2-\mathrm{cm}$ long by $1-\mathrm{cm}$ dia and contains $5 \mathrm{~A}$ molecular sieve cooled to $-45^{\circ} \mathrm{C}$. This trap removes any radon that was not adsorbed in the radon pre-trap $(f)$.

The last trap in the xenon purification step, the "final charcoal trap" (m), contains the same material as the main charcoal trap, though its volume is much smaller. The dimensions of this trap are approximately $6-\mathrm{cm}$ long by $0.6-\mathrm{cm}$ dia. These dimensions were determined to be sufficient to trap all of the xenon flowing 
from the main charcoal trap at $\sim 200 \mathrm{cc} / \mathrm{min}$ carrier gas flow when the final charcoal trap's temperature is kept below $-100^{\circ} \mathrm{C}$. Once the xenon is adsorbed in the final charcoal trap, it is transferred to the xenon quantification step by heating the final charcoal trap to $-400^{\circ} \mathrm{C}$ and letting the gas (typically $>50 \%$ xenon) expand into a pre-evacuated gas-cell scintillation counter (see Section 3.3).

The entire desorption/purification process takes 3 to 4 hours at $\sim 200 \mathrm{cc} / \mathrm{min}$ nitrogen carrier flow while transferring $>90 \%$ of the xenon trapped on the main charcoal trap onto the final charcoal trap.

\subsection{Xenon Quantification}

The xenon quantification step consists of electron-photon coincidence counting of the radioxenon gas in a gas-cell scintillation counter (n), subsequent gas-composition analysis via a residual gas analyzer (0), and final transfer to one of several pre-evacuated archive bottles. The gas mixture is transferred from the final charcoal trap by first evacuating one of four gas-cell scintillation counters and then opening a small dead-volume valve between the cell and the trap. The gas cell's internal volume is $-6.4 \mathrm{cc}$, but the volume of the combination of the final charcoal trap, tubing, and valves downstream of the final charcoal trap is much smaller. We have observed transfer efficiencies $>80 \%$ of the xenon gas from the final charcoal trap into the counting cell. The gas in the counting cell is counted by requiring a beta particle and/or conversion electron to be detected in coincidence with a gamma or $\mathrm{x}$-ray in the NaI(TI) spectrometer (see Section 4.1). 


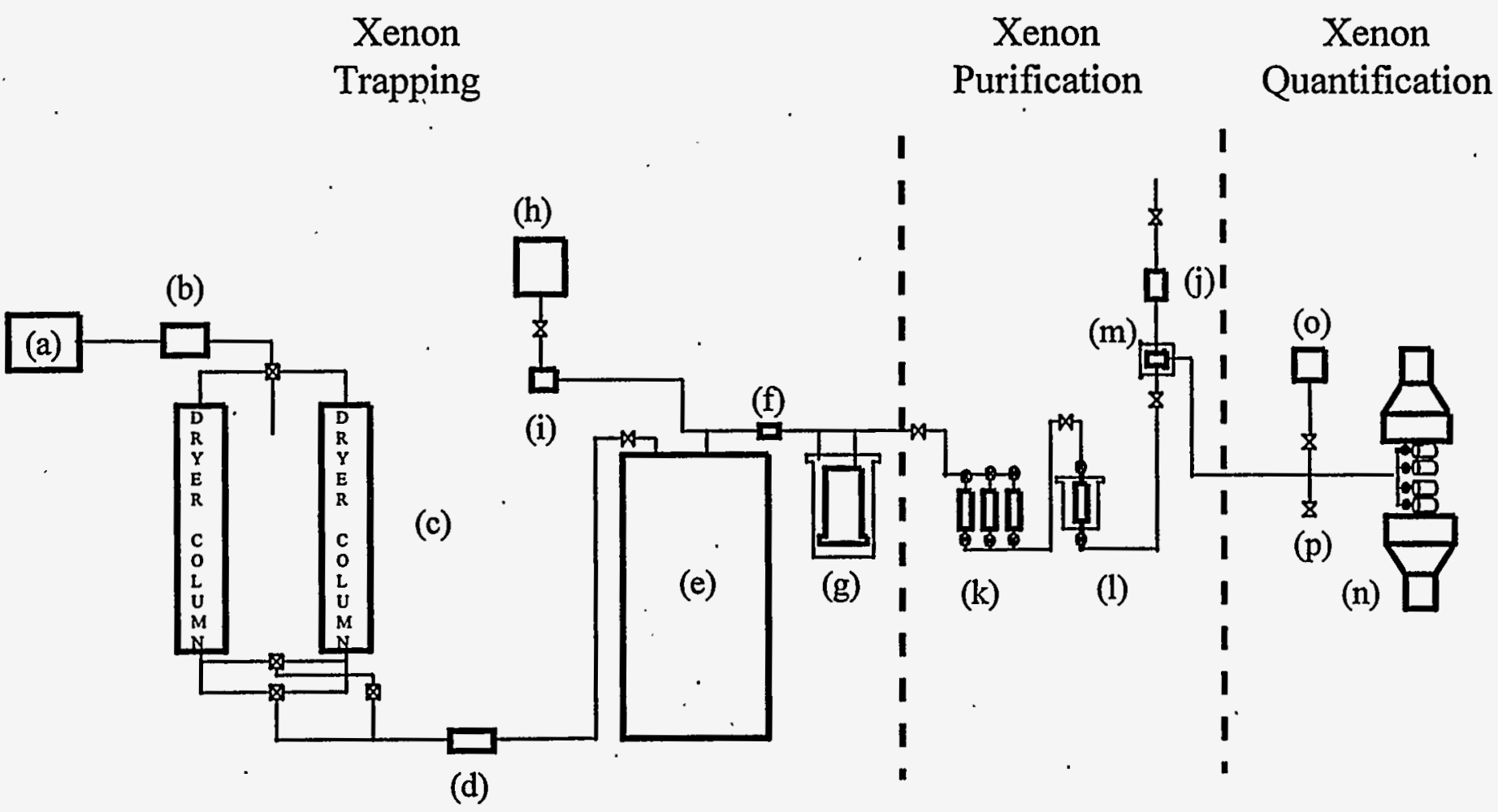

Figure 3.1. Schematic Illustration of Radioxenon Sampler/Analyzer. For simplicity, the components needed for $100 \%$ duty cycle are not shown. The system consists of (a) a piston compressor pump ( 80 to $100 \mathrm{psig}, 7 \mathrm{~m}^{3} / \mathrm{h}$ ), (b) heat exchanger, (c) dual air drying/ $\mathrm{CO}_{2}$ removal columns filled with $13 \mathrm{X}$ molecular sieve and $\mathrm{Al}_{2} \mathrm{O}_{3}$, (d) mass-flow controller for process air, (e) cryogenic air-chiller with output temperature $-125^{\circ} \mathrm{C}$, (f) initial radon "pre-trap," (g) cooled "main" charcoal trap for xenon trapping, (h) nitrogen bottle or generator, (i-j) mass flow controllers for nitrogen flow, $(k)$ ascarite-based $\mathrm{CO}_{2}$-removal traps (l), cooled 5A-molecular sieve radon removal trap, $(\mathrm{m})$ cooled, final small volume charcoal trap for xenon transfer into counting system, (n) NaI(TI)-scintillating gas cell based beta-gamma coincidence spectrometer, (0) quadrupole residual gas analyzer, (p) path to archive bottles. 
a)

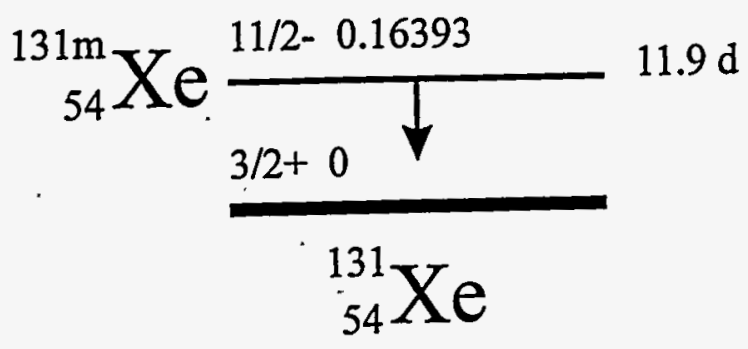

b)

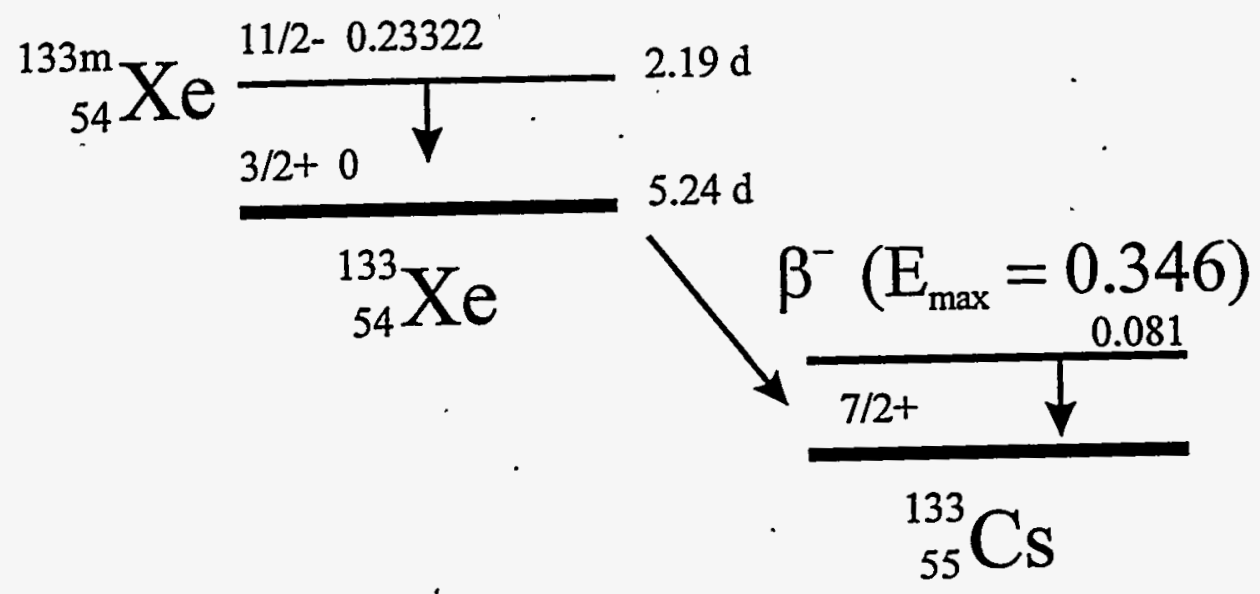

c)

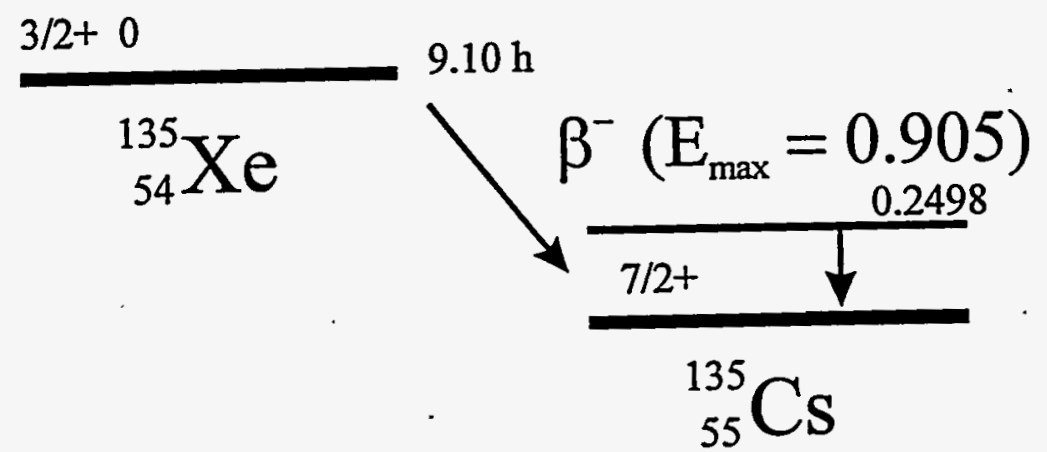

Figure 3.2. Nuclear Level Diagram for the Radioxenons of Interest: a) ${ }^{131 m} \mathrm{Xe}$, b) ${ }^{133} \mathrm{Xe}$ and $\left.{ }^{133 m} \mathrm{Xe}, \mathrm{c}\right){ }^{135} \mathrm{Xe}$. The levels shown are in MeV. Because of internal conversion of the gamma rays (in which an orbitalelectron and an $\mathrm{x}$-ray are emitted), only $2 \%, 37 \%, 10 \%$, and $90 \%$, respectively, of the gamma rays are
emitted. 



\subsection{Measuring the Radioxenons}

The primary concern in radioxenon monitoring for compliance to a CTBT is to detect nuclear-weapons-related radioxenon in the presence of ambient atmospheric radioxenon. Essentially all ambient radioxenon is from continuous reactor leakage, whereas the nuclear-weapons radioxenon of interest would be from rapid (few minutes) venting of a subsurface detonation or other nuclear detonation. Based on the radioxenon activity ratios from subsurface weapon tests venting, and reactor leakage shown in Figures 2.10 and 2.11 , it is clear that excellent differentiation is possible provided radionuclides can be measured selectively and sensitively.

\subsection{Radioxenon Decay Properties and Measurements}

The principal photons (gamma rays and $\mathrm{x}$-rays) and electrons (beta particles and conversion electrons) emitted by the xenon radionuclides are summarized in Table 4.1. In all of the cases described below, a primary decay mode of the radioxenon in question is through emitting a beta (or conversion electron) in prompt time coincidence with an $\mathrm{X}$-ray or gamma ray. It is this feature that allows for very sensitive measurements of these xenon radionuclides. With large $\mathrm{NaI}(\mathrm{Tl})$ detectors used for the gamma-ray measurements, we have observed that beta and/or capture-electron and gamma- or x-ray coincidence counting provides a $10^{3}$ - to $10^{4}$-fold background reduction relative to standard gamma-ray spectrometry (in singles mode). Since the beta and conversion-electrons are detected with high efficiency in the gas-cell scintillation counters, ${ }^{(x)}$ the total gamma-ray and $x$-ray detection efficiencies are not significantly reduced by requiring a coincidence event.

Xenon-131m decays via an isomeric transition wherein a $163.9-\mathrm{keV}$ gamma ray may be emitted (see Figure 3.2a). However, this transition energy is about $98 \%$ internally converted, resulting in near monoenergetic orbital electrons (conversion electrons) being ejected with energies of $163.9 \mathrm{keV}$ minus the binding energy of the conversion-electrons. The vacant electron orbit is instantly reaccupied, causing a xenon $\mathrm{x}$-ray to be emitted. Its energy depends on the orbit being reoccupied ( 30 to $34 \mathrm{keV}$ ). The principal $\mathrm{x}$-rays emitted in coincidence with conversion-electrons are summarized in Table 4.1.

The decay of ${ }^{133 m \mathrm{Xe}}$ (see Figure $3.2 \mathrm{~b}$ ) also involves an isomeric transition where the principal gamma ray $(233.2 \mathrm{keV})$ is internally converted about $90 \%$ of the time. Thus, a similar spectrum of $\mathrm{x}$-rays and a considerably higher energy conversion-electron (199 keV) are emitted. It is also possible to measure this radionuclide with very high sensitivity by coincidence counting.

Xenon-133 decays by emitting a 346-keV maximum energy beta particle with greater than a $99 \%$ branching ratio, in coincidence with an $81-\mathrm{keV}$ gamma ray. The $81-\mathrm{keV}$ gamma ray is internally converted so that it will only be emitted in $-37 \%$ of the decay processes. Therefore, while a beta-particle will always be emitted in the decay process, in $37 \%$ of the processes, a beta-gamma coincidence will occur, and in most of the other decay processes ( $-49 \%$ ), a beta-particle, a conversion-electron, and a 30 to $34-\mathrm{keV}^{133} \mathrm{Cs} \mathrm{x}$-ray will all be emitted in coincidence.

In ${ }^{135} \mathrm{Xe}$ decay (see Figure 3.2c), a 910-keV maximum energy beta particle will be emitted in coincidence with a $250-\mathrm{keV}$ gamma ray (branching ratio $=96 \%$ ). In this case, less than $10 \%$ of the $250-\mathrm{keV}$ gamma rays undergo internal conversion.

(a) Details of the counting system are to be submitted as an internal PNNL report (1996). Written by PI. Reeder, T.W. Bowyer, and R.W. Perkins. 
As one can see from Figures 3.2a through $3.2 \mathrm{c},{ }^{131 m \mathrm{Xe}}{ }^{133} \mathrm{Xe}$, and ${ }^{133 m \mathrm{Xe}}$ all have similar decay modes in that they emit a charged particle (beta and/or conversion electron) in coincidence with an $x$-ray of energy 30 to $34 \mathrm{keV}$. Since all of the radioxenons are measured simultaneously, it is not possible to separate the contributions from each radionuclide based on photon spectrometry alone. The ${ }^{133} \mathrm{Xe}$ activity level can be differentiated from ${ }^{131 m} \mathrm{Xe}$ and ${ }^{133 m} \mathrm{Xe}$ since it emits an $81-\mathrm{keV}$ gamma ray and beta with a $37 \%$ branching ratio when it decays. Without measuring the electron/beta energy (see Section 4.2), it is not generally possible to differentiate the signal strengths from ${ }^{131 m X e}$ and ${ }^{133 m} \mathrm{Xe}$, unless the decay rate of the 30 to $34-\mathrm{keV}$ signals is measured. Fortunately, ${ }^{131 m X e}$ is not produced in significant quantities in nuclear detonations compared to ${ }^{133 m} \mathrm{Xe}$ and ${ }^{133} \mathrm{Xe}$, and the ambient levels of ${ }^{131 \mathrm{~m} X e}$ and ${ }^{133 m X e}$ are expected to be quite small (see Section 4.2), so it is unlikely that the relative radionuclide strengths would be difficult to distinguish.

Since both ${ }^{133} \mathrm{Xe}$ and ${ }^{133 m \mathrm{Xe}}$ are produced in large amounts in nuclear detonations, we can use the known ratio of the $81-\mathrm{keV}$ gamma-ray peak to the $30-$ to $34-\mathrm{keV}$ peaks \{unresolved in $\mathrm{NaI}(\mathrm{Tl})$ \} for ${ }^{133} \mathrm{Xe}$ to determine its contribution versus that from ${ }^{133 m} \mathrm{Xe}$. This ratio can be determined if the detection efficiency for the photon peaks is known, which can be obtained by measuring a "pure" ${ }^{133} \mathrm{Xe}$ source such as radioxenon from a reactor. Since the amount of ${ }^{133 m} \mathrm{Xe}$ in a sample is determined by measuring the beta/electron-gated 30- to 34-keV X-ray photopeaks, any ${ }^{133} \mathrm{Xe}$ also in the sample will present an interference that must be subtracted. The statistical precision to which the ${ }^{133} \mathrm{Xe}$ contribution can be subtracted out is affected by the amount of ${ }^{133} \mathrm{Xe}$ in the sample. Shown in Figure 4.1 is the minimum detectable level of ${ }^{133 \mathrm{~m}} \mathrm{Xe}$ in the presence of varying levels of ${ }^{133} \mathrm{Xe}$. Even in relatively high levels of ${ }^{133} \mathrm{Xe}\left(\sim 2 \mu \mathrm{Bq} / \mathrm{m}^{3}\right)$, the minimum detectable level of ${ }^{133 \mathrm{~m} X e}$ is still $\sim 170 \mu \mathrm{Bq} / \mathrm{m}^{3}$. At low levels of ${ }^{133} \mathrm{Xe}$, the minimum detectable level of ${ }^{133 \mathrm{~m} X e}$ is dominated by the other unrelated background and counting statistics and equals about $20 \mu \mathrm{Bq} / \mathrm{m}^{3}$.

\subsection{Detection System Design}

If the material between the beta/conversion electron source and the detector is minimized, each event can be precisely energy analyzed for both the photon and the betas/electrons of interest. In our current gas cell scintillation detector setup, we have very little energy loss for even the lowest energy $(-45 \mathrm{keV})$ conversion electrons. It is thus possible, in principle, to measure with even higher sensitivity and selectivity by using energy windows for each isotope. Figure 4.2 illustrates schematically the photon-electron energy-energy correlation expected from the various radioxenons described above. Our preliminary studies using the gas-cell scintillation counters with radioactive spikes show that some degree of selectivity is possible, even though the energy resolution obtained with the gas-cell scintillation counter was not optimized. Also, the organic scintillator is not the optimal detector choice for this application. Our future studies in this area will seek to optimize pulse-height resolution from the existing gas-cell scintillation detectors and options for replacing the gas-cell scintillation counters with special-design silicon-wafer-based cells. To minimize system complexity for our initial prototype field-ready instrument, we have chosen to use beta and conversion-electron information as a gate only for the photon; this still has the effect of enormous background reduction and hence a highly sensitive measurement.

To obtain electron-/beta-gated photon energy spectra in a manner compatible with our automatic separation process, a gas-cell scintillation counter was developed as illustrated in Figure 4.3. This scintillation counter consists of a hollow cylinder with a 1-mm wall thickness, 1-mm-thick end-cap sections, and a volume of approximately $6.4 \mathrm{cc}$. The cell is viewed through each end-cap with a 1.9-cm-diameter photomultiplier tube. To record an event in the gas-cell scintillation counter, an event must be observed by each phototube within a coincidence time window. The sum of these two signals could provide a measure of the energy of the incident electron, and can therefore serve to enhance the sensitivity and selectivity. 
The wall thickness of the scintillation counter is sufficient to stop all of the beta particles or conversion electrons and provide a measure of their approximate energy, except for the few higher energy beta particles emitted by ${ }^{135} \mathrm{Xe}$ (maximum beta energy $910 \mathrm{keV}$ ).

A laboratory prototype detection system employed two 7.6-cm thick by $12.7-\mathrm{cm}$-diameter NaI(TI) detectors to detect the gamma/x-rays; however, a new NaI(TI)-based detection system has been designed that increases the geometric solid-angle coverage considerably (see Figure 4.4). The new detection system will accommodate four gas-cell scintillation counters for counting four xenon gas samples simultaneously. Since a beta and/or a conversion-electron event in a given gas cell triggers storage of an associated gamma ray or $x$-ray as part of a specific photon spectrum, four separate gas samples could be measured simultaneously. Figure 4.5 illustrates a beta coincidence gamma-ray spectra of a ${ }^{133} \mathrm{Xe}$ spike (containing some ${ }^{131 \mathrm{~m} X \mathrm{Xe}}$ ) taken with our prototype counting system with and without the coincidence requirement. This shows the ${ }^{133} \mathrm{Xe}$ photopeak at $81 \mathrm{keV}$ and the associated unresolved $\mathrm{x}$-ray peaks due to xenon and cesium $\mathrm{x}$-rays at 30 to 34 $\mathrm{keV}$. The extremely low gamma-ray background provided by the coincidence requirement permits xenon measurement of a few disintegrations per hour. We have gone to some lengths to maximize and determine the efficiency of the laboratory prototype using ${ }^{133} \mathrm{Xe}$ and other radioactive spikes. The calibration procedure we employed, along with more details on the detection system, is described elsewhere ${ }^{(n)}$.

Another counting system that has not yet been fully tested will consist of a gas-cell scintillation counter that will be located in the center of a large annular intrinsic germanium detector. This system uses more electrical power than the $\mathrm{NaI}(\mathrm{Tl})$-based system, but may reduce the background (perhaps an additional 10 -fold) and provide better suppression interference from radioactive contaminants from ambient radioactivity and in the final gas sample. This system has been simulated by placing the gas-cell scintillation counter on top of a large $\{-60 \%$ relative to $\mathrm{NaI}(\mathrm{Tl})\}$ intrinsic germanium detector and operating this detector system in the same coincidence counting mode as that required with the NaI(Tl) detector system. Studies are underway to determine optimal detector geometry and cost/power/sensitivity trade-offs for such a detection system.

(a) Details of the counting system are to be submitted as internal PNNL report (1996). Written by P.L. Reeder, T.W. Bowyer, and R.W. Perkins. 


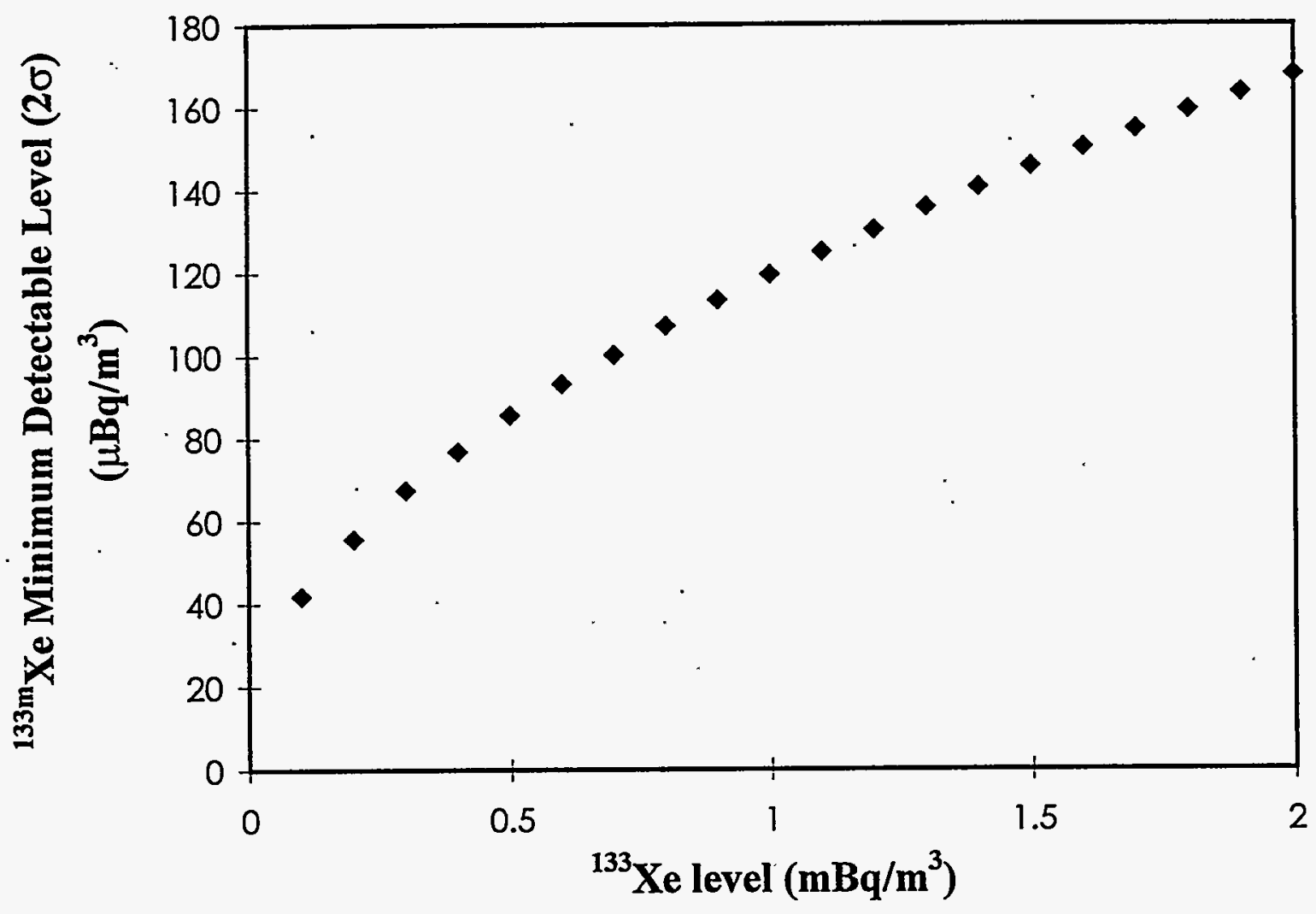

Figure 4.1. Xenon-133m Minimum Detectable Level (Two Standard Deviations Above Background) Versus Ambient Level of ${ }^{133} \mathrm{Xe}$, Dominated by the Uncertainty in the ${ }^{133} \mathrm{Xe}$ Level. In the absence of ${ }^{133} \mathrm{Xe}$, the minimum detectable level is $20 \mu \mathrm{Bq} / \mathrm{m}^{3}$, dominated by counting statistics and uncorrelated background. 


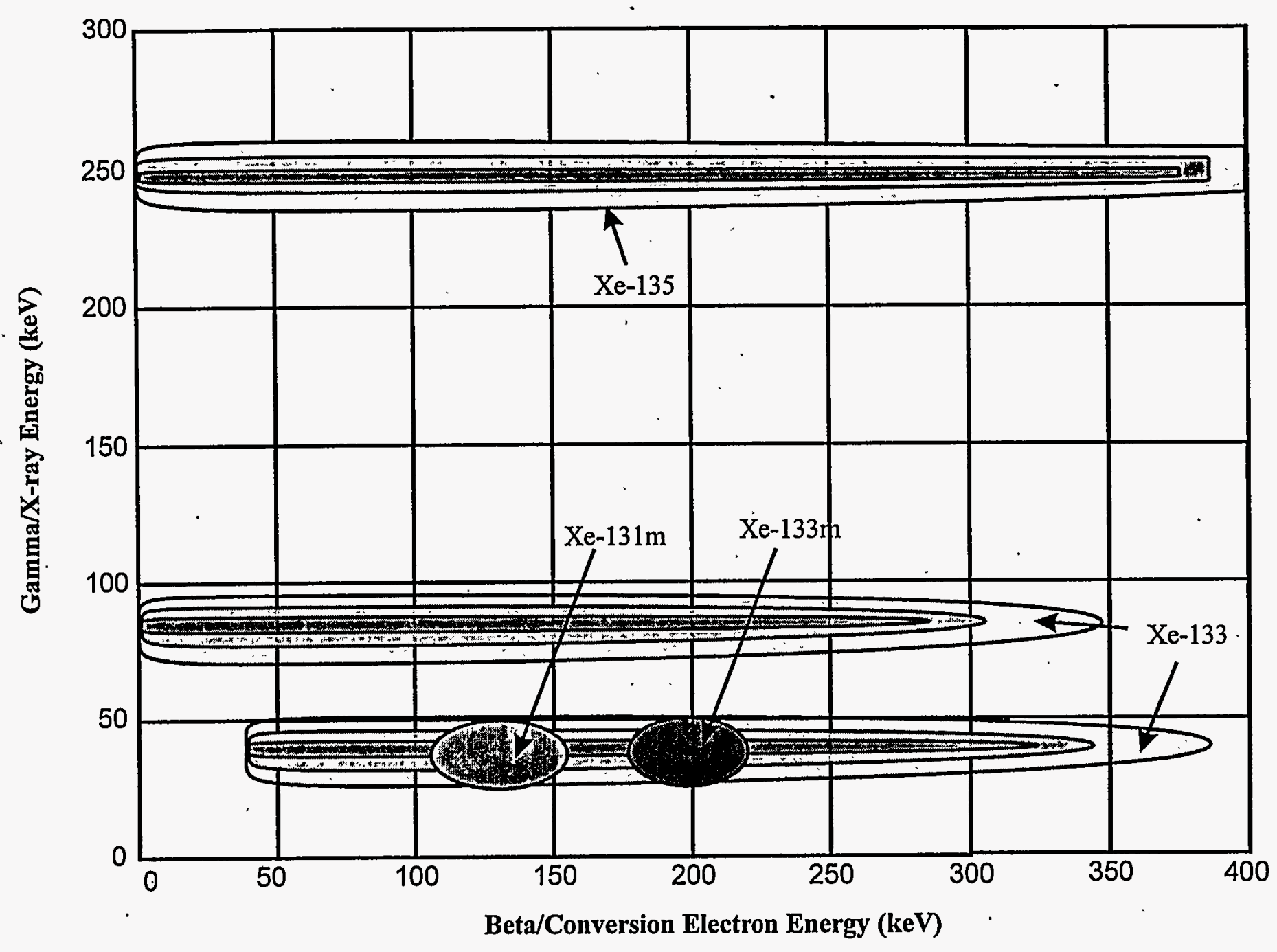

Figure 4.2. Artist's Rendition of Two-Dimensional Energy-Energy Correlation for the Radioxenons of Interest. With Beta/conversion-electron energy measurement, some sensitivity/discrimination improvements should be possible. 

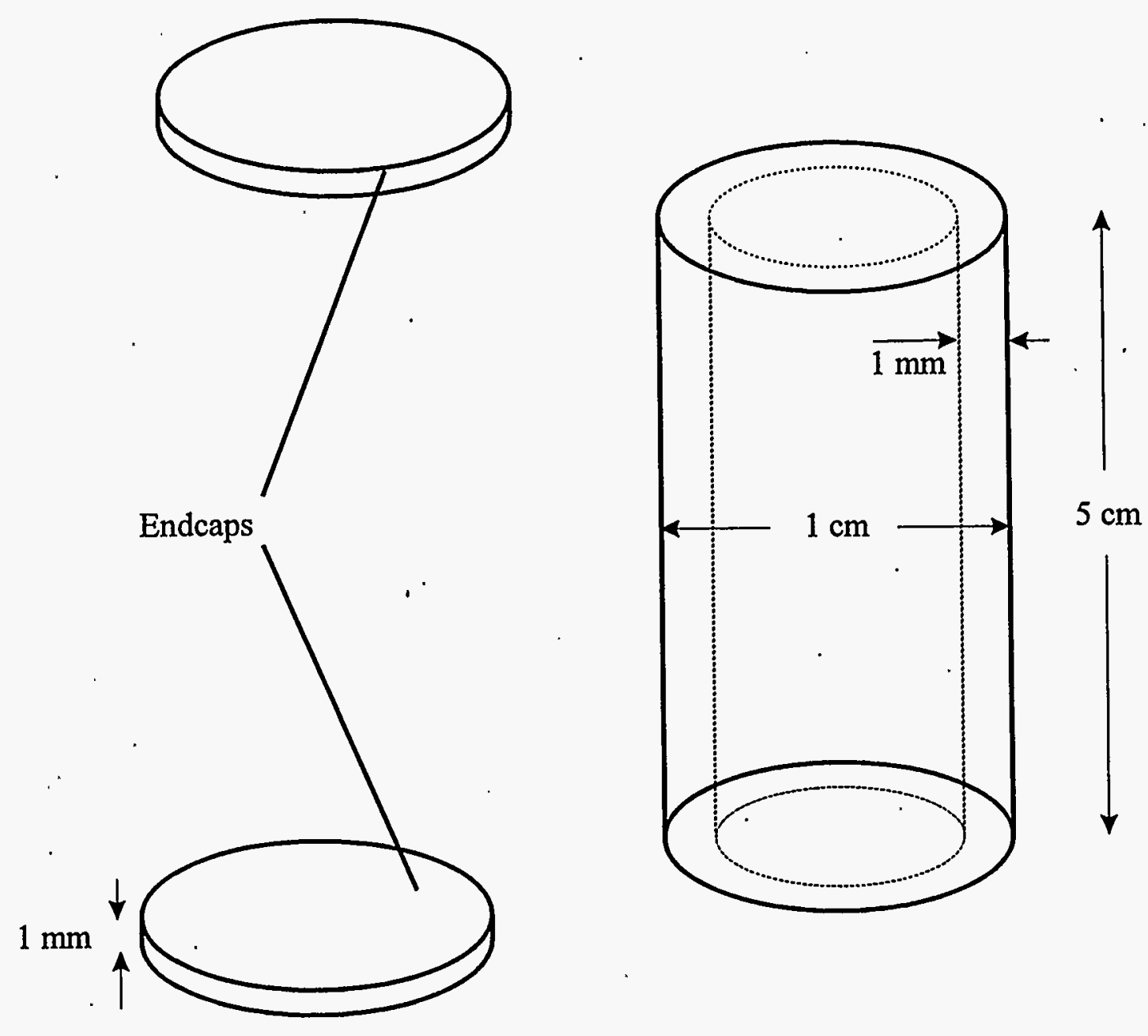

Figure 4.3. Schematic Illustration of Scintillating Gas-Cell Used for the Beta-gamma Coincidence Spectrometer. The end-caps shown are glued onto the ends of the hollow cylinder, and photomultiplier tubes are attached on each end. 


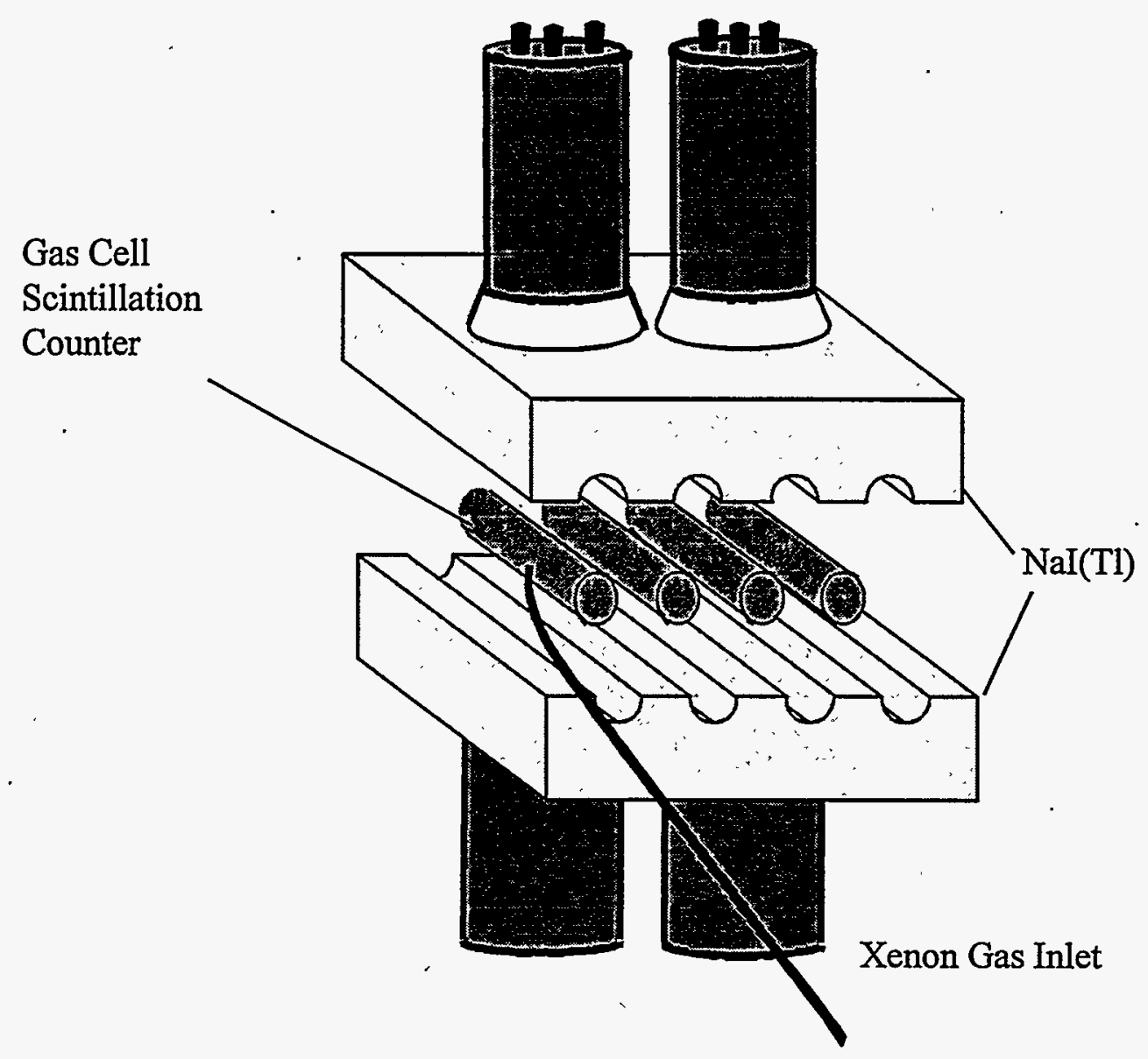

Figure 4.4. Improved $\mathrm{NaI}(\mathrm{Tl})$ Beta-gamma Coincidence Spectrometer 


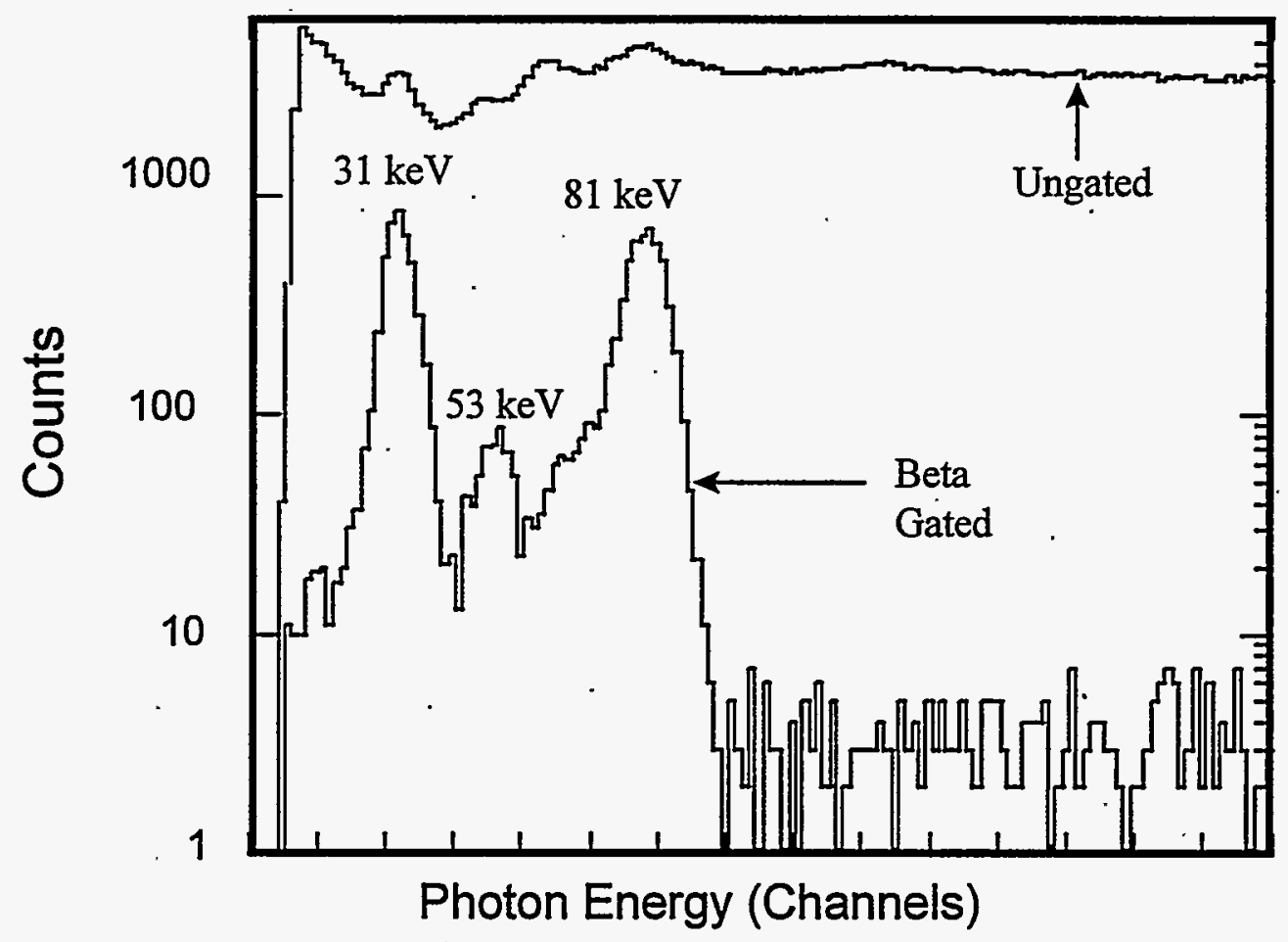

Figure 4.5. Gamma-Ray Spectrum Taken with Current NaI(Tl) Beta-Gamma Coincidence Spectrometer with and Without Beta/electron Gating of the Photon 
Table 4.1 Principle Emissions of the Radioxenons

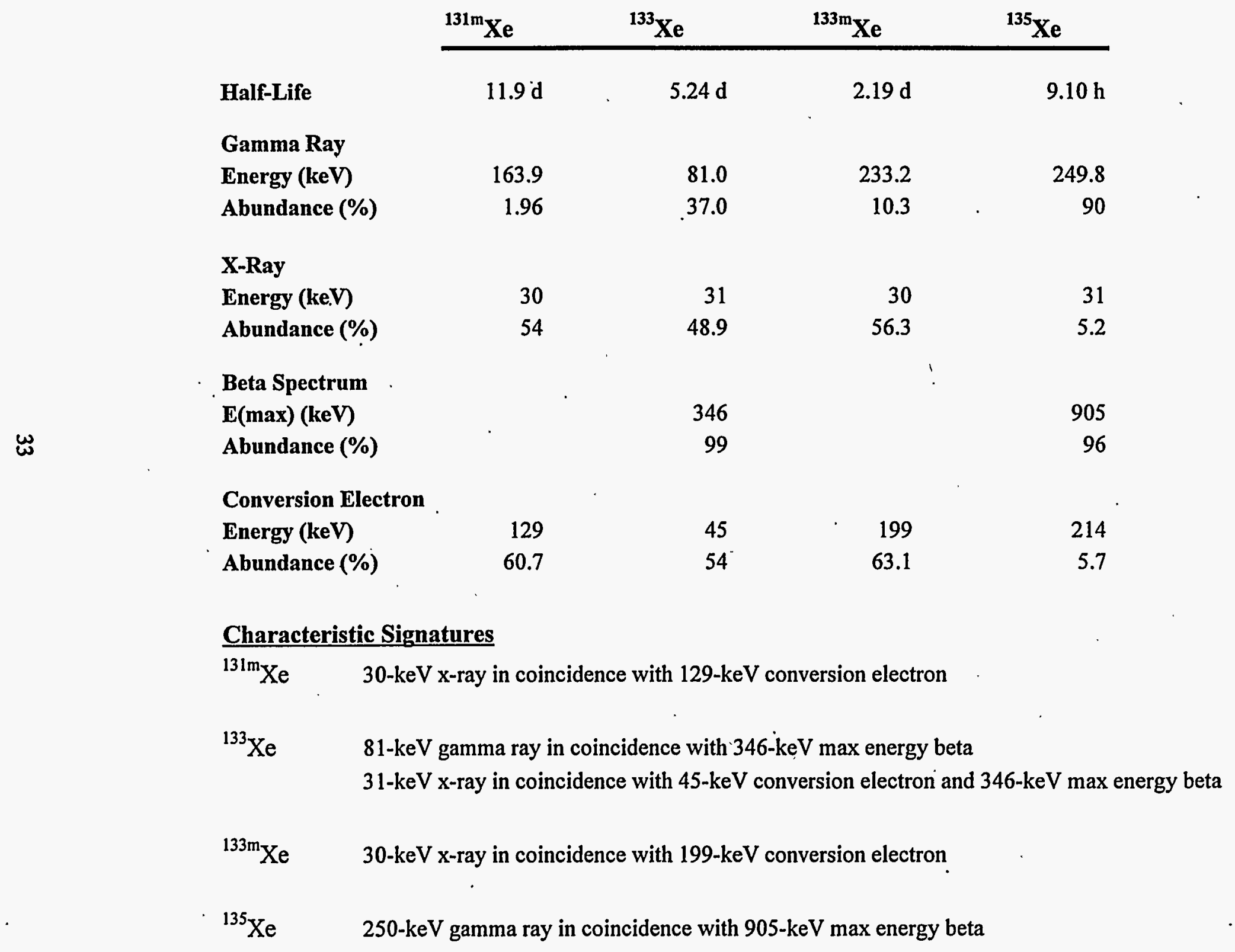





\subsection{Future Work and Summary}

Figure 5.1 shows a computer aided design (CAD) rendering of an engineering field model scheduled to begin initial testing and calibrations in August 1996. It should be ready for field tests in early 1997 . All of the system operations will be automatic and computer-controlled, including state-of-health monitoring, capability of remote programming, automatic transmission of gamma-ray spectral data, and calculations of the radioxenon concentrations, if required. The spectral data, together with gas and radionuclide compositions, permit the radioxenon concentrations to be calculated, and all of these data will be transmitted to a data center at the conclusion of each analysis. However, if the radioxenon concentrations are found to exceed specified limits at any time during the counting period, these preliminary data can be automatically transmitted.

A near real-time automatic xenon radionuclide analyzer has been developed that permits the atmospheric ${ }^{131 m X e}{ }^{133 m} \mathrm{Xe},{ }^{133} \mathrm{Xe}$, and ${ }^{135} \mathrm{Xe}$ to be measured continuously. By measuring activity concentrations of these radionuclides, it is possible to differentiate between vented material from a subsurface or other nuclear detonation where particulate radionuclide release is minimal and other sources, such as emissions from nuclear reactors, fuel reprocessing, and medical isotope production and usage. Compared with previously reported laboratory-based analytical methods, this is the first automatic, high-sensitivity system developed for measuring atmospheric xenon radionuclides, providing a 100 - to 1000 -fold greater sensitivity for the short collection/analysis periods of interest. The current system design incorporates the following specifications: 1) continuously separates xenon from the atmosphere at a flow rate of 4 to $10 \mathrm{~m}^{3} / \mathrm{h}$ for 6 to 12 hours, 2) measures ${ }^{131 \mathrm{~m}} \mathrm{Xe},{ }^{133} \mathrm{Xe},{ }^{133 \mathrm{~m}} \mathrm{Xe}$, and ${ }^{135} \mathrm{Xe}$ with a sensitivity of 20 to $100 \mu \mathrm{Bq} / \mathrm{m}^{3}$ during a subsequent 12 - to 36-hour period, 3) automatically transmits photon spectra and radionuclide concentrations to appropriate designated organizations, 4) reports abnormally high concentrations of xenon radionuclides as soon as statistically valid data have accumulated, 5) operates automatically, and 6) can be programmed remotely. 


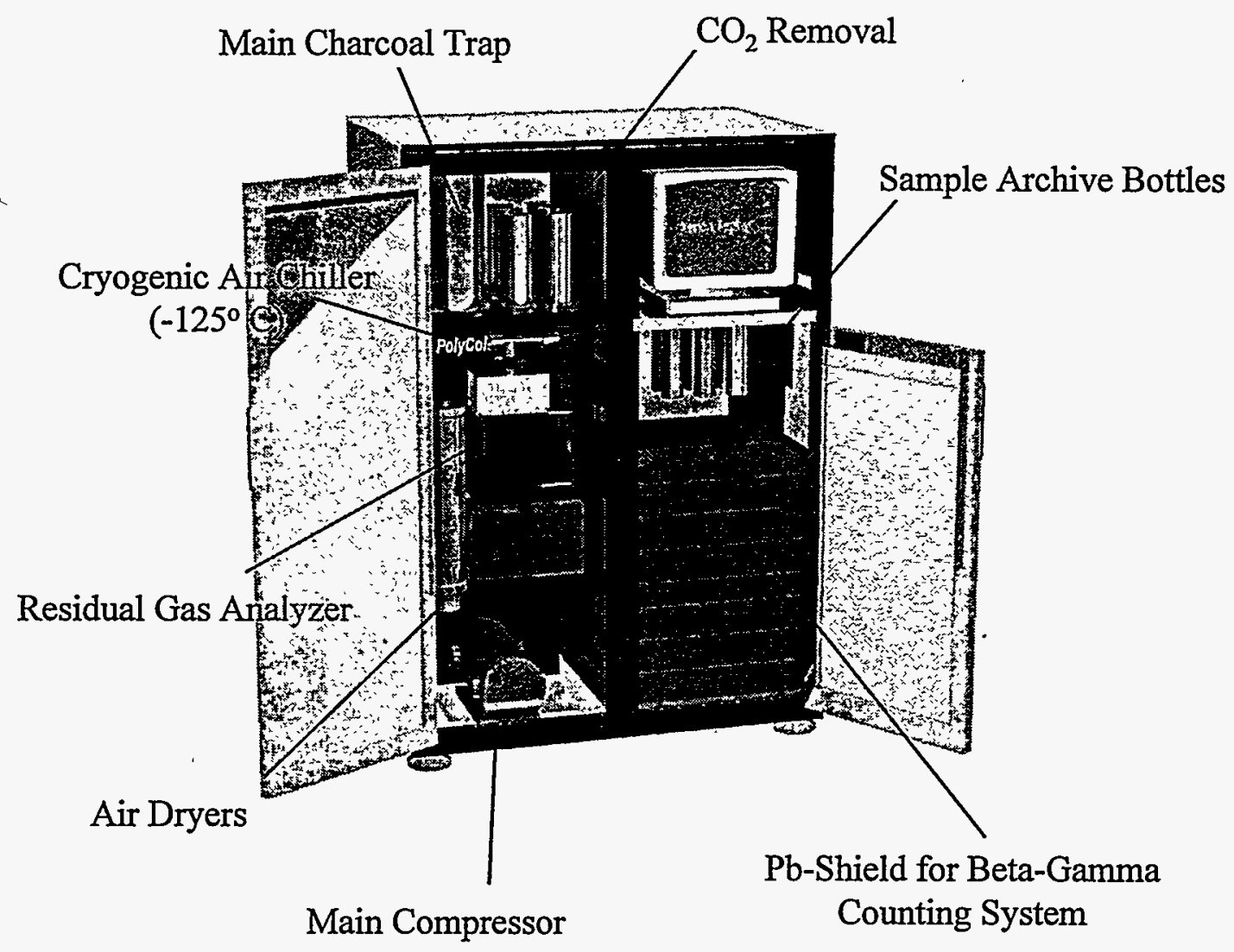

Figure 5.1. Cad Rendering of Engineering Field Model to Be Tested Starting in January, 1997 


\subsection{References}

Bernstrom, B., and Lars-Erik DeGeer. 1983. Xenon-133 I Luft. FOA Rapport, C-20515-A1, Forsvarets Forskningsanstalt, Huvudavdelning 2, 10254 Stockholm, Sweden.

Bolmsjo, M.S., and B.R.R. Persson. 1982. "Factors Affecting the Trapping Performance of Xenon Holdup-Filters in Nuclear Medicine Applications." Med. Phys. 9(1).

Bowyer, T.W., K.H. Abel, W.K. Hensley, M.E. Panisko, and R.W. Perkins. 1996. Ambient ${ }^{133}$ Xe Levels in the Northeast U.S., PNNL-SA-27197, Pacific Northwest National Laboratory, Richland, Washington.

Ihara, H. ed., 1989. Tables and Figures from JNDC Nuclear Data Library of Fission Products, Version 2, JAERI-M 89-204.

Kunz, C.O. 1973. "Separation Techniques for Reactor-Produced Noble Gases." In Noble Gases, eds. Richard E. Stanely and Alan Moghissi, pp. 209-217. Report No. EPS/600/9-76/026, NTIS Accession No. PB-259 085/9, National Technical Information Service (NTIS), Washington, DC.

Kunz, C. 1989. "133Xe Ambient Air Concentration in Upstate New York." Atmos. Environ., 23(8):1827-1833.

Kunz, C.O., and C.J. Paperiello. 1976. "Xenon-133: Ambient Activity from Nuclear Power Stations." Science 192(4245):1235-1237.

Pence, D.T, C.C. Chou, J.D. Christian, and W.J. Paplawsky. 1978. "Noble Gas Separation with the use of Inorganic Adsorbents." In Proceedings of the 15th DOE Nuclear Air Cleaning Conference, CONF 780819, Pt. 1, pp. 512-519.

Perkins, R.W., and U.P. Jenquin. 1994. Identification of Radionuclides of Concern in Hanford site Environmental Cleanup. PNL-10060, Pacific Northwest Laboratory, Richland, WA.

\subsection{Bibliography \\ (Not called-out references)}

Bolmsjo, M., and B.R.R. Persson. 1978. "Trapping and Re-Use System for Radioactive Xenon in Nuclear Medicine." 'Phys. Med. Biol. 23(1):78-79).

Bolmsjo, M. 1981. The Physical and Physiological Aspects of Xenon Isotopes in Nuclear Medical Applications. Thesis. Lund University, Lasarettet, S-221 85, Lund, Sweden.

Hensley, W.K., H.S. Miley, and R.W. Perkins. 1995. "Automated Airborne Radionuclide Monitoring." In CTBT Monitoring Technologies Conference 1995 Proceedings, Paper RN-3. Advanced Research Projects Agency, Arlington, Va. 
Horrocks, D.L. 1973. "Measurement of Radioactive Noble Gases by Liquid Scintillation Techniques." In Noble Gases, eds. Richard E. Stanley and A. Alan Moghissi, pp-199-208. Report No. EPA/600/9-76-026, NTIS Accession No. PB-259 085/9, NTIS, Washington, DC.

Kolde; H.E., W.L. Brinck G.L. Gels, and B. Kahn. 1973. "Radioactive Noble Gases in Effluents from Nuclear Power Stations." In Noble Gases, eds. Richard E. Stanley and A. Alan Moghissi, pp. 100-108. Report No. EPA/600/9-76/026, NTIS Accession No. PB-259 085/9, NTIS, Washington, DC.

Langford, J., and G. Thompson. 1990. "Monitoring Radioactive Xenon Gas in Room Air Using Activated Charcoal". J.Nucl. Med.Tech., 18(1):40-43.

LeBlanc, A.D., H.J. Evans, P. C. Johnson, and G. Timpe. 1979. "A Technique for Measurement of Xenon-133 in Air Contamination." J. Nucl. Med., 20:981-985.

Matuszek, J.M., C.J. Paperiello, and C.O. Kunz. 1973. "Reactor Contributions to Atmospheric Noble Gas Radioactivity Levels." In Noble Gases, eds. R.E. Stanley and A.A. Moghissi, pp. 360-364. Report No. EPA/600/9-76/026, NTIS Accession No. PB-259 085/9, NTIS, Washington, DC.

Matsuoka, N., N. Momoshimą, T. Okai, Y. Takashima, and N. Shiraishi. 1988. "An Approved Apparatus for the Determination of Krypton-85 and Xenon-133 in an Emergency Situation." J. of Radioanal. and Nucl. Chem., 120(1):21-27.

Murphy, P.H., and N.S. Anderson, 1975 "Inexpensive, Convenient Xenon Disposal." Health Physics 29(5):779-780.

Newton, J.C., F.B. Stephens, and R.K. Stump. 1973. "Determination of Trace Noble Gases in Air and Natural Gas." In Noble Gases, eds. R.E. Stanley and A.A. Moghissi, pp. 218-224. Report No. EPA/600/9-76/026, NTIS Accession No. PB-259 085/9, NTIS, Washington, DC.

Paperiello, C.J. 1973. "An Internal Gas-Proportional Beta-Spectrometry for Measurement of Radioactive Noble Gases in Reactor Effluents." In Noble Gases, eds. R.E. Stanley and A.A. Moghissi, pp. 239-248. Report No. EPA/600/9-76/026, MTIS Accession No. B-259 085/9, NTIS, Washington, DC.

Perkins, R.W., H.S. Miley, W.K. Hensley, and K.H. Abel. 1995 "Airbome Radionuclides of Concern and Their Measurement in Monitoring a Comprehensive Test Ban Treaty." In Monitoring a Comprehensive Test Ban Treaty, eds, E.S. Husebye and A.M. Dainty, pp. 143-155. NATO ASI Series, Series E: Applied Sciences, Vol. 303. Kluwer Academic Publishers, Boston.

Scarpitta, S.C., and N.H. Harley. 1990. "Adsorption and Desorption of Noble Gases on Activated Charcoal: I. ${ }^{133}$ Xe Studies in a Monolayer and Packed Bed." Health Phys., 59(4):383-392.

Schmauch, G.E. 1973. "A Cryogenic System for Collecting Noble Gases from boiling Water Reactor Off-Gas." In Noble Gases, pp. 296-301. In Noble Gases, eds. R.E. Stanley and A.A. Moghissi, pp. 24-28. Report No. EPA/600/9-76/026, NTIS Accession No. B-259 085/9, NTIS, Washington, DC.

Smith, J.M. 1973. "Experience with Radioactive Noble Gases from Boiling Water Reactors." In Noble Gases, eds. R.E. Stanley and A.A. Moghissi, pp. 81-89. Report No. EPA/600/9-76/026, NTIS Accession No. B-259 085/9, NTIS, Washington, DC. 
Smith, A.R., E.L. Field, and R.L. O'Mara. 1973. "Cryogenic Adsorption Systems for Noble Gas Removal." In Noble Gases, eds. R.E. Stanley and A.A. Moghissi, pp. 326-335. Report No. EPA/600/9-76/026, NTIS Accession No. B-259 085/9, NTIS, Washington, DC,

Stein, L. 1973. "Chemical Methods for Removing Xenon and Radon from Contaminated Atmospheres." In Noble Gases, eds. R.E. Stanley and A.A. Moghissi, pp. 376-385. Report No. EPA/600/9-76/026, NTIS Accession No. B-259 085/9, NTIS, Washington, DC.

Underhill, D.W., D.C. DiCello, L.A. Scaglia, and J.A. Watson. 1986. "Factors Affecting the Adsorption of Xenon on Activated Carbon." Nucl. Sci. Eng., pp. 411-414.

Van Der Mark, Th. W., R. Peset, W. Vaalburg, A.E.C. Rookmaker, and M.G. Woldring. 1977. "Storage and Retrieval of Waste ${ }^{133} \mathrm{Xe}$." Intl. J. of Appl. Rad. Iso. 28(6):602-604.

Wahlen, M., C.O. Kunz, J.M. Matuszek, W.E. Mahoney, and R.C. Thompson. 1980. "Radioactive Plume from the Three Mile Island Accident: Xenon-133 in Air at a Distance of 375 Kilometers." Science 207:639-640. 


\section{Distribution}

No. of Copies

Offsite

2 DOE Office of Scientific and Technical

Communication

Alfred Bedard

NOAA, Environmental Technology

Laboratory .

Mail Code R/E/ET4

325 Broadway

Boulder, Colorado 80303-3328

William A. Jester

Radiation Science and Engineering Center

The Pennsylvania State University

University Park, Pennsylvania 16802

Sheldon Landsberger

Department of Nuclear Engineering

University of Illinois-214 Nuclear

Engineering Lab

103 South Godwin Avenue

Urbana, Illinois 61801-4798

John Lucas

Nuclear Test Branch (TMAT)

AFTAC

1030 S. Hwy A1A

Patrick Air Force Base, Florida 32925

Capt. Matthew Murdough

Nuclear Test Branch (TMAT)

AFTAC

1030 S. Hwy A1A

Patrick Air Force Base, Florida 32925

Charles F. McBrearty, Jr.

Director, Materials Technology (TM)

AFTAC

1030 S. Hwy A1A

Patrick Air Force Base, Florida 32925
No. of Copies

Offsite

L. Evanson. NN-42

Intl. Policy \& Analysis Div., GA-007

U.S. Department of Energy

1000 Independence Avenue S.W.

Washington D.C. 20585

M.F. O'Connell NN-20

Office of Research \& Development, GA-033

U.S. Department of Energy

1000 Independence Avenue S.W.

Washington D.C. 20585

L.A. Casey NN-20

Office of Research and Development,

GA-033

U.S. Department of Energy

1000 Independence Avenue S.W.

Washington D.C. 20585

Onsite

26 Pacific Northwest National Laboratory

K.H. Abel

T.W. Bowyer (10)

W.K. Hensley

C.W. Hubbard

A.D. McKinnon

M.E. Panisko

R.W.Perkins

PL. Reeder

D.E. Robertson

R.C. Thompson

R.A. Warner

N.A. Wogman

Technical Report Files (5)

Distr. 1 